\title{
Morphometric and structural diagnosis of fault reactivation in the Cenozoic: a case study of the Blumenau-Soledade Lineament in southern Brazil
}

\author{
Eduardo Salamuni ${ }^{1 *}$ (D), Clauzionor Lima da Silva ${ }^{2}$ (D), Edenilson Roberto do Nascimento ${ }^{1}$ (D),

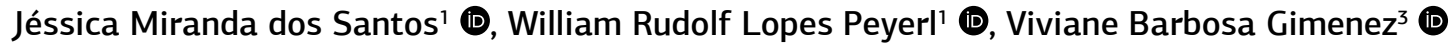

\begin{abstract}
The hypothesis that geomorphometric parameters and structural-geological features are diagnostic of reactivation of the Blumenau-Soledade Lineament in central-western Santa Catarina, Brazil was tested by confronting data on asymmetry, elongation, morphological markers, drainage patterns, and river anomalies of the Pelotinhas catchment and structural data for the Serra Geral Group (Paraná Basin). The results indicate reactivation of the lineament as a dextral strike-slip fault, as the cause of an associated morphostructure characterized by an escarpment along the left bank of the river as well as being responsible for catchment asymmetry and morphometric anomalies. Although fault data indicate paleostress correlatable to regional tectonic events described in the literature, we propose that the earliest paleostress pulse possibly was active during the Paleocene-Eocene transition, with $\sigma_{1}$ oriented NE-SW and $\sigma_{3} \mathrm{NW}$-SE. In the early Paleogene, the stress system evolved as an extensional pulse. During the Paleogene and early Neogene, the paleostress field rotated with reorientation of the $\sigma_{1}$ axis between NNW and NNE. The current tectonic regime was established between the Late Pleistocene and Holocene, with compressional stress $\sigma_{1}$ oriented approximately WNW-ESE and $\sigma_{3}$ NNE-SSW, as it generally occurs in the South American Plate.
\end{abstract}

KEYWORDS: tectonic pulses; morphotectonics; paleostress.

\section{INTRODUCTION}

Typically found in active plate boundaries, fast-evolving landscape changes in tectonically active areas allow for a comprehensive view of their relief forming processes, which, when analyzed in combination with the existing geological structures, can help to clarify the orientation of the stress fields they are subjected to. In an intraplate environment in southern Brazil with the crystalline shield sand rocks of the Paraná Basin, research has led to the determination of Paleogene, Neogene, and Quaternary elements and stress fields that modify the current relief. A number of authors have addressed the problem in south and southeastern Brazil (Riccomini et al. 1989, Flores et al. 1991, Frasca and Lisboa 1993, Souza Filho 1995, Schuck et al. 2001, Tomazzoli and Pellerin 2001, Tomazzoli 2002, Salamuni et al. 2004, Fortes et al. 2005, Grohmann et al. 2007, Andrades Filho and Guasselli 2008,

\footnotetext{
${ }^{1}$ Universidade Federal do Paraná - Curitiba (PR), Brazil. E-mail: salamuni@ufpr.br,mirandas.jessica@gmail.com, williampeyerl@hotmail. com,deni_ern@ufpr.br

${ }^{2}$ Universidade Federal Rural do Rio de Janeiro - Seropédica (RJ), Brazil. E-mail: clauzionor_silva@hotmail.com

${ }^{3}$ Universidade Estadual Paulista "Júlio de Mesquita Filho" - Rio Claro (SP), Brazil. E-mail: vivianebgimenez@hotmail.com.br

${ }^{*}$ Corresponding author.
}

Chavez-Kus and Salamuni 2008, Franco et al. 2008, Roldan et al. 2010, Kröhling et al. 2011, Reis and Tomazzoli 2011, Santos et al. 2011, Machado et al. 2012, Morales et al. 2012, Nascimento et al. 2013, Souza Junior et al. 2013, Nummer et al. 2014, Jacques et al. 2014, Oliveira et al. 2016). The difficulties in carrying out such studies in mountainous areas with thin regolith and little Cenozoic sedimentary cover have been circumvented by recognizing reactivated Precambrian and Paleozoic structures, tectonic relief and drainage control, and distinguishing of Neogene to Quaternary events. The integration of morphological data such as catchment symmetry, slope and knickpoints to satellite imagery, DEMSRTM (Digital Elevation Model-Shuttle Radar Topography Model) and geological-structural data has allowed tectonic factors controlling relief and drainage to be satisfactorily identified in Brazil (Saadi et al. 2002, Salamuni et al. 2004, Costa and Saadi 2005, Etchebehere et al. 2006, Zalán and Oliveira 2006, Hiruma et al. 2010, Soares et al. 2011). The present study confirms previous qualitative approaches by authors such as Freitas (1950), King (1956), Bjornberg et al. (1971), Asmus and Ferrari (1978), Twidale (1985), Hasui (1990), Saadi (1993), Assumpção (1998), Borges et al. (1998), Hasui et al. (1998), Lima (1998), Lima and Valadão (2002) and Valadão (2009).

This article aims to demonstrate that correlations between geomorphometric parameters and geological-structural characteristics can diagnose reactivation of the BlumenauSoledade Lineament in Mid-west Santa Catarina, Brazil. 
The hypothesis was tested by integrating asymmetry data, stretching, morphological markers, drainage patterns, anomalies in the rivers of the Pelotinhas hydrographic basin, and tectonic-structural data from the Serra Geral Formation (Paraná Basin).

The research was carried out in the hydrographic basin of the Pelotinhas River, a tributary of the Pelotas River, in the southeast of Santa Catarina, Brazil. The area stretches along for $830 \mathrm{~km}^{2}$, within latitudes $28^{\circ} 27^{\prime} \mathrm{S}$ and $27^{\circ} 55^{\prime} \mathrm{S}$ and longitudes $50^{\circ} 40^{\prime} \mathrm{W}$ and $50^{\circ} 05^{\prime} \mathrm{W}$ in the municipalities of Lages and Capão Alto on the São Joaquim plateau (Fig. 1).

Evidence that the catchment is morphostructurally conditioned by the reactivation of the Blumenau-Soledade Lineament (Fig. 2) allows for advanced studies to be carried to characterize the local evolution of a wide peneplain, from intraplate tectonics, although the processes involved are slower and more subtly noticed than the ones along the South American Plate border.

The present work, in addition to broadening the knowledge on regional Cenozoic tectonics, served to provide a better understanding of which approaches are more appropriate for the objective to be achieved. In addition, a correlation with the Andean neotectonic framework, at least at the same latitude, showed that the present regional stress has a tectonic consequence, even if weak in intraplate regions.

\section{MATERIALS AND METHODS}

The study involved a geomorphometric analysis of morphostructures from satellite imagery and DEM-SRTM (Nasa 2017), as well as a geometric and kinematic analysis of faults. Identifying geomorphometric aspects is essential in morphotectonic studies as they allow the degree of tectonic activity of a given region to be inferred (Keller and Rockwell 1984, Hare and Gardner 1985, Schumm 1986, Keller and Pinter 2002, Bull 2007, Garrote et al. 2008, Burbank and Anderson 2012). Geomorphological methods involving tectonic elements are usually applied to relatively stable intraplate regions of low seismicity, as it is the case in southern Brazil.

\section{Cartography}

The map base of the study includes the São Sebastião do Arvoredo Sheet (SH.22-XA-II, 1979) and the Coxilha Grande Sheet (SH.22-XAI, 1973), from the Geographical Service of the Brazilian Army, and the Lajes Sheet (SG.22ZCV, 1973), from the Brazilian Institute of Geography and Statistics (IBGE). The regional geological map is based on the Geological Map of the State of Santa Catarina (Wildner et al. 2004). Geomorphological data were also collected and analyzed from SRTM data with resolution of $30 \mathrm{~m}$ ( 1 arc second) and ALOS PALSAR data (High Resolution Observation Mode - single polarization 2007/11/20).

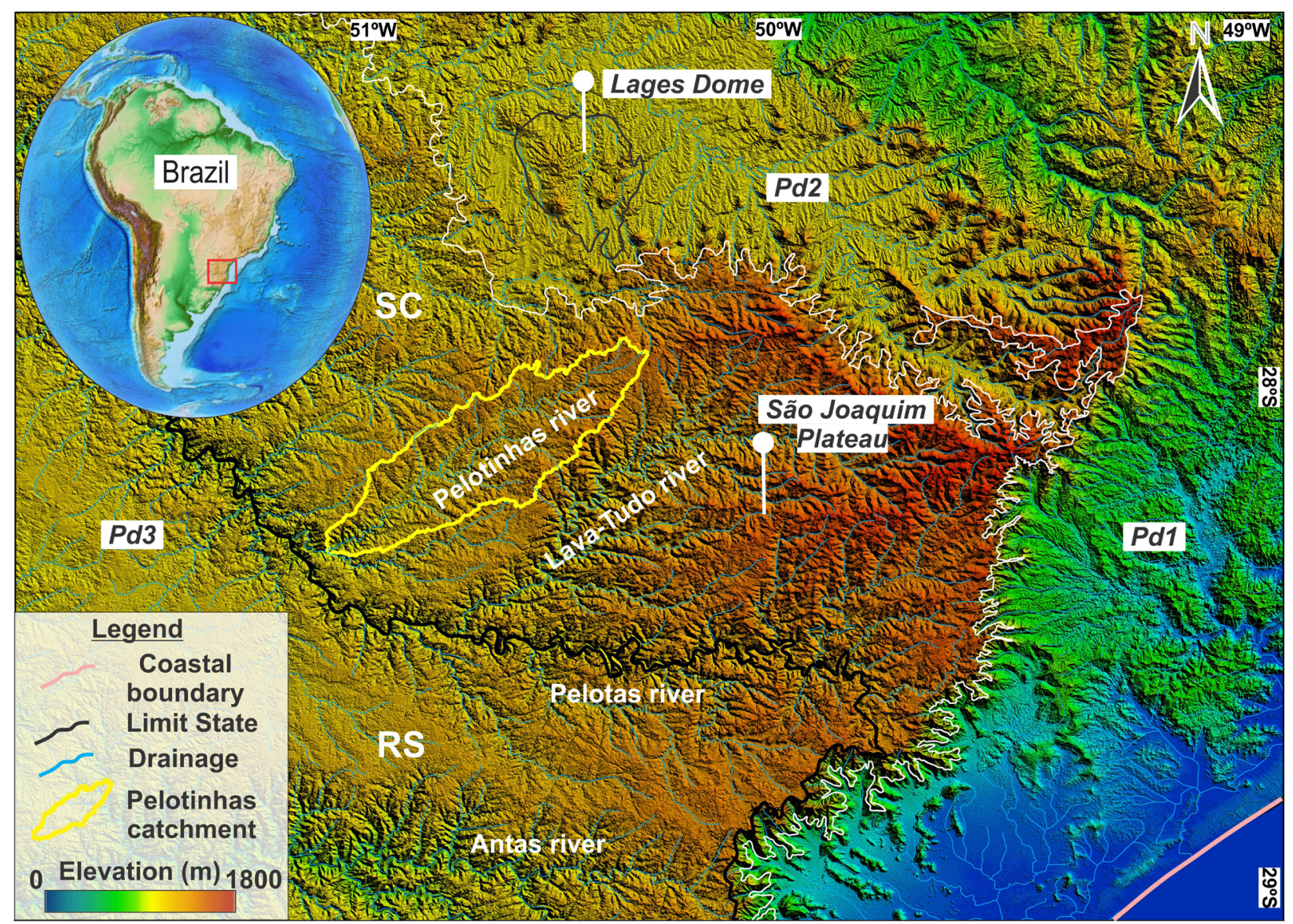

Figure 1. Regional topography map showing Pelotinhas and Pelotas rivers, and broad plateau areas (Pd3 and Pd2) in Santa Catarina and Rio Grande do Sul, Brazil, where remnants of local erosion surfaces are present. The main regional morphostructures are the coastal plain (Pd1), the Serra Geral escarpment, the Lages Dome, and the São Joaquim Plateau. Note: Pd represents the regional pediplane surfaces from the erosion of the original surface. 


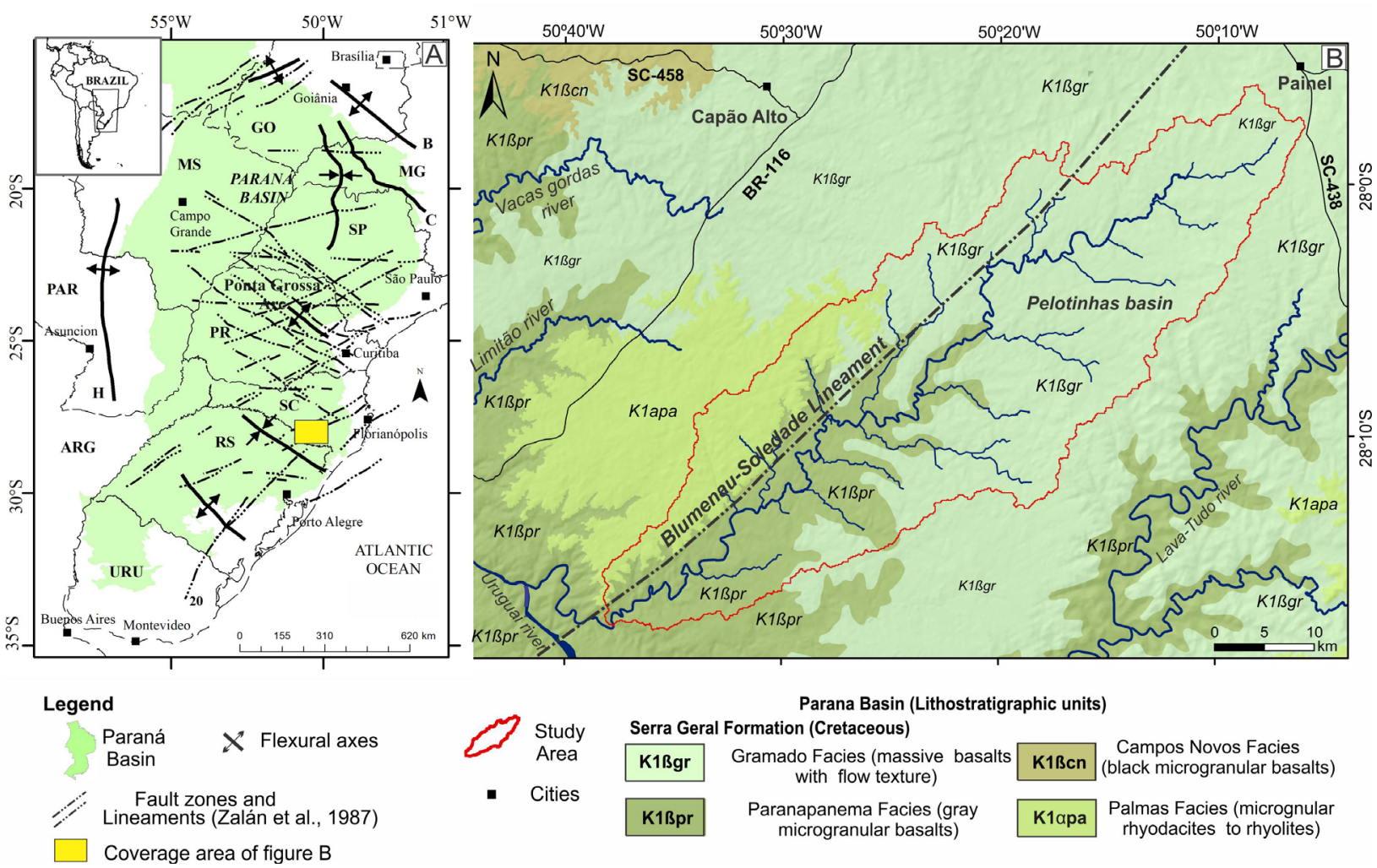

Figure 2. The Pelotinhas catchment in the geological context of the Serra Geral Formation. Geophysical lineaments that affect the Paraná Basin are shown on the left (Zalán et al. 1987). The Blumenau-Soledade Lineament and its geological setting are depicted on the right (Wildner et al. 2004).

\section{Relief analysis}

DEM-SRTM images were used to identify morphostructures and automatic tracing of hypsometric and slope maps in ArcGIS $10.3^{\circledR}$. Relief lineaments were drawn at the scale of 1:100,000. Swath-profiles were plotted according to the method of Pérez-Peña et al. (2017) using the SwathProfile tool in ArcGIS $10.3^{\circledR}$. For each mean profile, 50 uniformly spaced 4-km wide profiles were drawn parallelly to a central line showing minimum, mean, and maximum elevations.

Drainage network analysis followed Ouchi (1985) and Holbrook and Schumm (1999). To identify potential tectonic tilting, the asymmetry of the Pelotinhas catchment was calculated using the Hare and Gardner (1985) factor as expressed in Equation 1:

$\mathrm{AF}=100^{*}\left(\mathrm{~A}_{\mathrm{r}} / \mathrm{A}_{\mathrm{t}}\right)$

Where:

$\mathrm{Ar}=$ the area occupied to the right bank of the main channel downstream;

At $=$ the total area of the catchment.

AF values higher or lower than 50 indicate the degree of asymmetry and, possibly, the tilting direction.

The elongation of the catchment area was calculated in accordance with Bull (2007) to clarify the relationships between its geometry and the existing morphostructural features (structural lineaments). The elongation of a drainage system in total equilibrium is equal or close to 1 . When elongation is close to 0 , the catchment is interpreted as being in a process of reorganization/adjustment to some relatively fast geomorphometry-changing event. The elongation coefficient, according to Schumm (1956), is given by Equation 2:

$\operatorname{Re}=\mathrm{Rc} / \mathrm{L}$

Where:

$\mathrm{Re}=$ the elongation;

$\mathrm{Rc}=$ the diameter as calculated from the radius of an ideal circular catchment;

$\mathrm{L}=$ the length of the main channel.

\section{Optically stimulated luminescence geochronology}

Sediment dating was performed by optically stimulated luminescence (OSL) of quartz and feldspar in Quaternary sedimentary deposits to obtain information on the sedimentation ages of the quaternary deposits. Samples were collected from abandoned channels in PVC tubes that were approximately 40 $\mathrm{cm}$ long, with one end closed so that the sediments would not be exposed to any kind of white light (sunlight). Collecting the samples in the field is simple, a PVC tube is inserted into the slope and removed once it has been filled. One of the ends is closed with a temporary cover to avoid sunlight exposure. As the success of the method depends on the degree of saturation of the material being dated (Aitken 1998), only two of the eight samples collected yielded reliable ages. The analysis was carried out at the Dating and Dosimetry Laboratory of 
Universidade Federal de São Paulo (UNIFESP), where the samples were segregated to check natural radioactive elements that could provide the annual dose of exposure to sunlight by Gamma Spectrometry. The amount is approximately $85 \mathrm{~g}$ of sediment, which was dried ( 24 hours) in an oven at $43^{\circ} \mathrm{C}$. With the sample sealed in a "sample holder", the reading is made in a Germanium detector after 15 days.

\section{Knickpoint analysis}

Knickpoints along longitudinal river profiles were determined using the Hydrology tool in ArcGIS $10.3^{\circledR}$, with MATLAB R2012a post-processing. For integration with other geomorphometric data, the map showing the distribution of knickpoints and knickzones was superimposed to a DEM-SRTM. The procedure followed the algorithm of Harbor et al. (2005), which yields smoothed channel profiles and graphical representations of their altimetric deviations against steady state profiles, thus allowing graphical correlations between gradient and slope to be plotted (Snyder et al. 2000, Whipple and Meade 2004, Harkins et al. 2007, Kirby et al. 2007).

\section{Structural analysis}

Structural data were obtained by both satellite photointerpretation and DEM-SRTM modeling. Field structural readings of fault and joint attitudes were also taken. In the various outcrops visited in road cuts and small quarries, structural data collection followed the kinematic characterization nomenclatures of Petit (1987) and Doblas (1998). Rose diagrams of structural lineaments and fault stereograms were drawn, both cyclographically and from paleostress calculations. The structural analysis was performed using AzimuthFinder software (Queiroz et al. 2014). In WinTensor, version 5.8.5 (Delvaux and Sperner 2003), specifically, structural data were grouped into six sets, each one covering a $30^{\circ}$ interval with four subsets of faults: normal, reverse, dextral strike-slip, and sinistral strike-slip.

\section{GEOMORPHOLOGICAL AND GEOLOGICAL SETTING}

In southern Brazil, the relief between the coastal zone where intense dissection formed the most recent pediplane (Pd1, Fig. 1) - and the interior of the continent is marked by a large escarpment step and by cuestas in an erosional process. A new pediplanar surface herein called Pd2 (Fig. 1) is being formed, as remnants of the oldest surface ( $\mathrm{Pd} 3)$, similar to that described by Bigarella et al. (1965) are still found in the region. In Santa Catarina, Pd3 is represented by the Tabuleiro Ridge (the Campos Gerais Plateau), along which the São Joaquim Plateau is located in the south central portion of the State. There, headwaters of the Uruguay River and its two main tributaries, the Canoas and Pelotas rivers, are partially controlled by structural lineaments oriented E-W and NNESSW (Kröhling et al. 2011). Around the study area, the morphology consists of separate pediments of moderate dissected relief, elongated interfluvia, tabular hills, and terraces with 50 to $100 \mathrm{~m}$ steps (Fig. 1).
Tributary to the Pelotas River, the Pelotinhas catchment reaches altitudes between 1,000 and 1,200 min a morphostructural context of lineaments cutting the regional topography. The catchment extends across the Paraná Basin over 133 to $134 \mathrm{Ma}$ old tholeiitic basalts, andesites, and rhyodacites of the Serra Geral Formation (The Paraná-Etendeka Large Igneous Province) of the Neojurassic-Eocretaceous Gondwana III Supersequence (Milani et al. 2007, Nardy et al. 2008, Thiede and Vasconcelos 2010, Janasi et al.2011), extensive basic volcanism that reached average and maximum thickness of 650 and $1,755 \mathrm{~m}$, respectively (Wildner et al.2006). Peate et al. (1992) grouped the lavas which formed these rocks into six facies. Microgranular gray basalts of the Paranapanema Facies and massive basalt flows of the Gramado Facies outcrop in the study area. Microgranular rhyodacites of the Palmas Facies are also present, limited to the northwest of the right banks of the catchment (Fig. 2).

Broad fault zones bounded by linear geophysical anomalies, arcs, and flexures compartmentalize the Paraná Basin (Fig. 2A). The main local linear feature that sections both the Precambrian basement and the basalt flows in the study area is the Blumenau-Soledade Lineament, oriented NE-SW (Ferreira 1982, Zalán et al. 1990, Artur and Soares 2002, Soares et al. 2007). The Cenozoic structural framework, in turn, includes Paleogene and Neogene faults. Recent faults oriented E-W and N-S and reactivated faults oriented NW-SE and NE-SW are present (Hasui 1990, Salamuni et al. 2004, Morales et al. 2012).

Located near the study area and relevant for the analysis presented herein is the remarkable Lages Dome in southeastern Santa Catarina corresponding to a structural high contemporary to alkaline magmas that intruded rocks of the Paraná Basin around $75 \mathrm{Ma}$ ago (Scheibe et al. 1985). Later, in the Miocene, the dome was affected by extensional tectonic events that caused drainage reorganization and tilting of topographical surfaces (Roldan et al.2010). Jacques et al. (2014) and Nummer et al. (2014) interpreted three deformational events responsible for the strike-slip faults in central-southern Santa Catarina and Rio Grande do Sul plateaus. According to these authors, during the Cretaceous, $\sigma_{1}$ was oriented $\mathrm{N}-\mathrm{S}$, while from Late Cretaceous to Paleogene, the compression field experienced a rotation to NE-SW. From the Neogene, $\sigma_{1}$ compression would have assumed an E-W orientation approximately (Assumpção 1998, Lima 1998, Salamuni et al. 2004).

\section{RESULTS}

\section{Morphometric analysis}

The Pelotinhas catchment stretches along $63 \mathrm{~km}$, covering an area of $830 \mathrm{~km}^{2}$ with a maximum width of $18 \mathrm{~km}$. The main channel incision resulted in a rectilinear and elongated valley, eventually forming canyons with concave-convex flanks, along which the river flows from northeast to southwest subsequently to the structural orientation of the BlumenauSoledade Lineament.

The Pelotinhas catchment area tilts slightly to northwest, as its asymmetry factor indicated displacement of the 
main channel ( $\mathrm{AF}=41.5)$ towards the right bank (Fig. 3). However, considering the catchment segmentation into three distinct areas (upper, middle and lower), a gradual increase in asymmetry is observed downstream of the main channel, with values corresponding to $32.5,40.5$, and 53.0, respectively. Regarding elongation ( $\mathrm{Re})$, the catchment has a value of 0.52 , which is compatible with geomorphological disequilibrium.

DEM-SRTM shows a $180 \mathrm{~m}$ altitude step between the main channel valley $(900 \mathrm{~m})$ and the highest parts of the right border of the Pelotinhas catchment (1,080 m) (Fig. 4, Profile A-B). Sixty-meter high escarpment faces and drainage segments parallel to NE-SW oriented structural lineaments form narrow, straight interfluves. The swath-profiles in Figure 4 show two different situations. In profile A-B, the main channel valley (downstream of Area 1) tends to symmetry, with preservation of topographic surfaces and the escarpment associated with the Blumenau-Soledade Lineament. In the C-D profile (Area 2), the main channel extends along an asymmetrical valley, while the Rio Lajeado do Arvoredo channel follows the Blumenau-Soledade Lineament at lower topographic levels (maximum and average values). Such a geomorphological configuration may be associated with capture and avulsion of the middle course of the Pelotinhas river. Local altitude steps indicate that along the post-Cretaceous structural lineaments the area is in process of tilting and dismantling.

Channels in the left bank of Pelotinhas catchment form rectangular, subdendritic and trellis patterns (Fig. 4). Channels in the right bank of the catchment, in turn, form parallel drainage systems typically found in obsequent rivers, with trellis and rectangular patterns and shorter segments.

Waterfalls and/or rapids along lineaments, paleochannels, and abandoned meanders are the main drainage anomalies in the Pelotinhas catchment. A waterfall at the Coxilha Rica farm (Point 23a, Figs. 4 and 5A) marks the course change of the Pelotinhas river, from NE-SW bordering the escarpment to SE following the NW-SE lineament that controls a small tributary channel (Point 23b, see Figs. 4 and 5B-5D). Small inflections along lineaments and fracture zones attest to the structural control of the catchment.

Rapids and river captures are present in the right-bank tributaries of the Pelotinhas river, like Batelão and Cachoeirinha creeks and the Lajeado Quimera River (Fig. 4). A thalweg incised in the bedrock usually lacking alluvial sedimentary cover, which is typical of youthful rivers, drains directly into the main channel, which is typical of rapid incision processes. Another aspect, mainly along the left-bank tributaries of the Pelotinhas river, is the abandonment of channels and lagoons. Such anomalies occur at altitudes of up to $1,200 \mathrm{~m}$ at tributary headwaters, like at Points 10 to 14 of Area 2 (Figs. 4 and $6 \mathrm{~A}-6 \mathrm{~B})$, being also present in the lower Pelotinhas river, where ponds and suspended valleys resulted from the avulsion of former channels (Area 3 - Fig. 4).

Table 1 shows optically stimulated luminescence (OSL) results for silty-clayey sediments from cutoff channels of the Pelotinhas river tributaries. Paleodose, annual dose, and final age were calculated from $\mathrm{Th}, \mathrm{U}$, and $\mathrm{K}$ isotope concentrations. In the first case, concerning an abandoned meander of a Pelotinhas river tributary (Point 18, Fig. 4), geomorphic evolution has been in process for at least 15.5 thousand years. In the second case, concerning sediments from an extensive abandoned channel (Point 19, Figs. 4 and 6C-6D), the river ceased to flow approximately 11,000 years ago in a paleoenvironmental scenario that was different from the current one. The data show, in summary, that the rivers and watercourses in the region are undergoing a transient adaptation process, possibly caused by the tectonic adjustment.

In the study area, drainage anomalies show a reorganization of the drainage network subjected to important structural control of relief, which characterizes disequilibrium in response to morphotectonic adjustments.

Figure 7A-7D highlights the distribution of knickpoints (green-to-red points representing slope variations) and longitudinal profiles of four main tributaries of the Pelotinhas catchment. The profiles result from smoothing of channel traces. To integrate relief data with morphotectonic elements of the
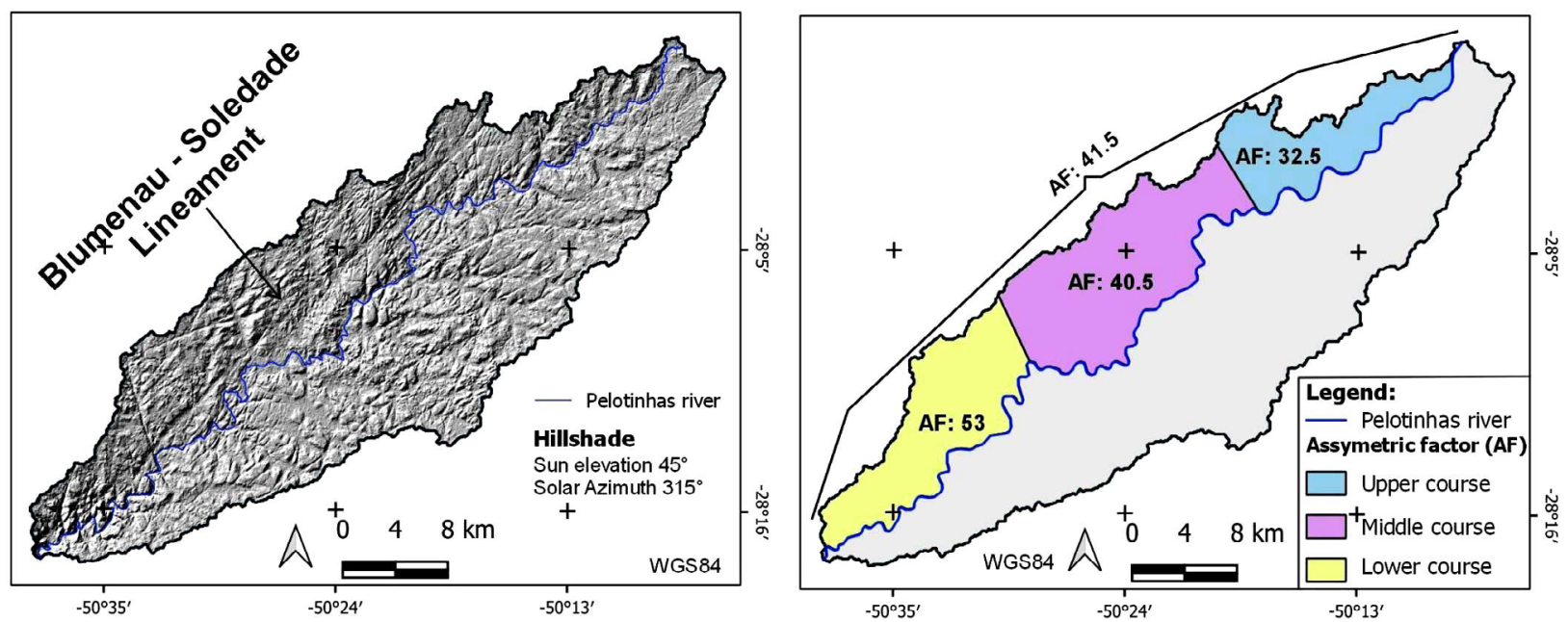

Figure 3. (A) Digital elevation model of the Pelotinhas catchment, by Alos-Palsar; (B) Asymmetry factor values for upper, middle and lower segments reflecting northwestward avulsion of the main channel in response to tilting. 

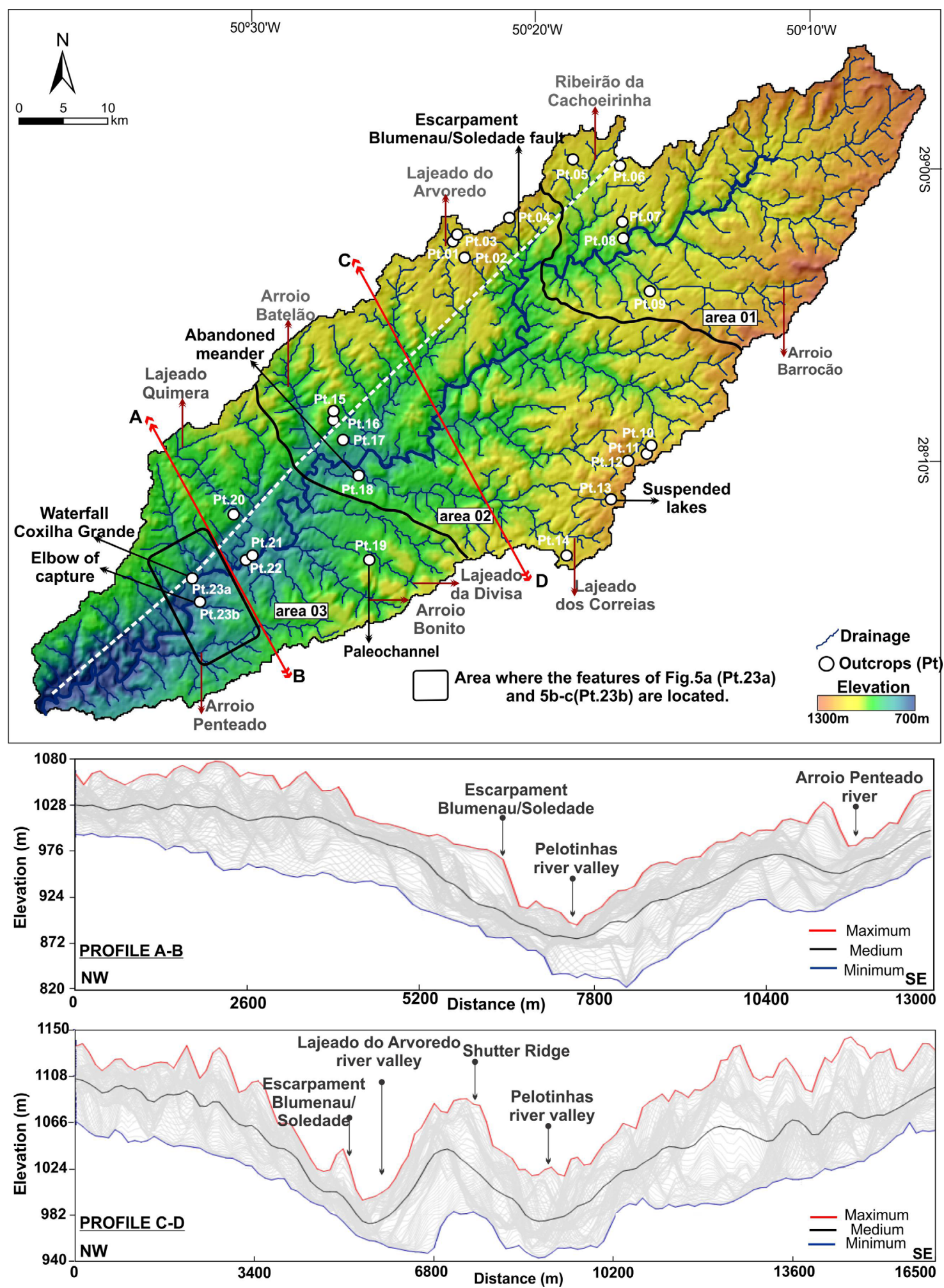

Figure 4. Hypsometric map obtained from DEM-SRTM modeling of the three segments that form the Pelotinhas catchment and their respective asymmetry values. Below, swath-profiles showing asymmetry of valleys, structural conditioning to the Blumenau-Soledade Lineament, and existing morphostructural features. Points $(\mathrm{Pt})$ indicate the outcrops visited.

study area, the main channel and two tributaries of either bank were selected. The main slope-break is located at an altitude of $850 \mathrm{~m}$ approximately, $20 \mathrm{~km}$ upstream of the Pelotinhas mouth (Point 23a, Fig. 4).

In the channel segments of Figures $7 \mathrm{~B}-7 \mathrm{C}$, red portions correspond to sharp channel slope breaks. Slope values decrease as the distance from the headwaters increases, showing the compatibility of the smoothed longitudinal profiles obtained through the routine of Harbor et al. (2005). Because the routine involves linear regression of altimetric data, it allows graphic comparisons between gradient and slope.

The knickpoints along the Pelotinhas river correspond to anomalously abrupt slope variations. The slope is gentle in the middle course of the river, but more pronounced in lower segments (see highlighted point in Fig. 7). The Pelotinhas river is an incision drainage with compressed meanders in its middle 

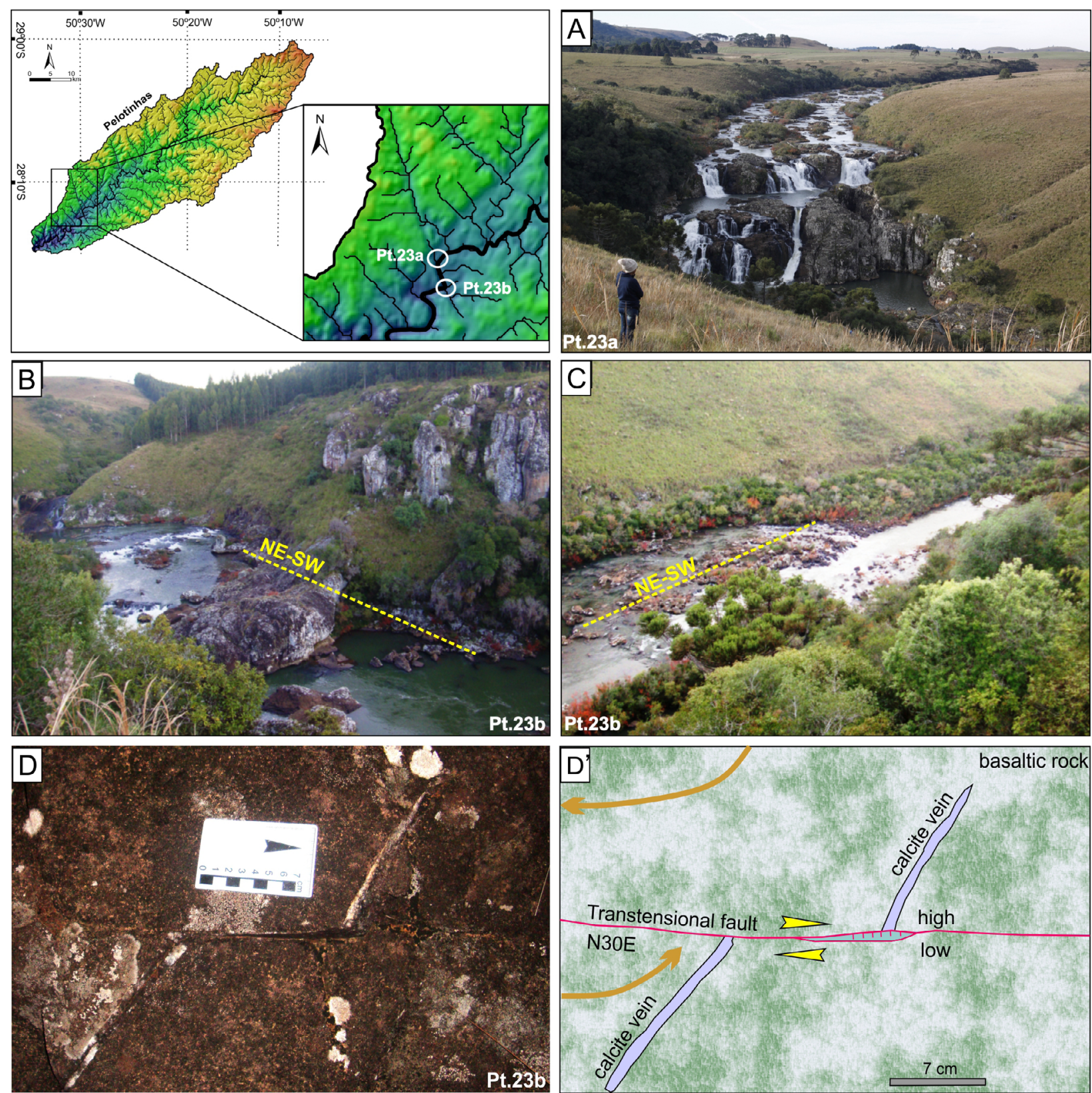

Figure 5. (A) Waterfall at the Coxilha Rica farm (Point 23a, Fig. 4) marking deflection of the Pelotinhas river to SE as controlled by a NW-SE lineament; (B) Morphostructural control of the river, with a tributary valley in the background and natural dam transposition controlled by fractures and NE-SW faults; (C) Structuring of rapids to NE-SW with insipient canyon downstream of the previous image; (D, D') Small N30E dextral-transtensional fault at the border of an incipient canyon cut into a Blumenau-Soledade Lineament related morphostructural feature.

Table 1. OSL dating of abandoned channel sediments from the Pelotinhas catchment: annual distribution of Th, U, K, and final calculated ages (collection points in Figs. 4 and 6C-D).

\begin{tabular}{|c|c|c|c|c|c|c|c|}
\hline $\begin{array}{l}\text { Sample } \\
\text { (depth m) }\end{array}$ & Coordinates & Th (ppm) & $\mathbf{U}(\mathbf{p p m})$ & $\mathbf{K}(\%)$ & $\begin{array}{c}\text { Annual Dose } \\
\text { (uGy/year) }\end{array}$ & $\operatorname{De}(\mathbf{G y})$ & Age (Kyear) \\
\hline Point 18 & $2808^{\prime} 51^{\prime \prime}$ & $12.2+-0.50$ & $2.41+-0.07$ & $0.02+-0.01$ & $1.586+-34$ & $15.0+-2.9$ & $15.5+-0.7$ \\
\hline $\begin{array}{l}(0.8 \mathrm{~m}) \\
\text { Point } 19\end{array}$ & $\begin{array}{l}5026^{\prime} 52^{\prime \prime} \\
2812^{\prime} 47^{\prime \prime}\end{array}$ & $8.82+-0.39$ & $1.43+-0.07$ & $0.02+-0.01$ & $1.173+-28$ & $12.3+-2.2$ & $11.0+-1.0$ \\
\hline
\end{tabular}

and lower courses. A succession of rapids and waterfalls characterizes knickzones associated with particular base-level drops. A knickzone can be observed near the headwaters $90 \mathrm{~km}$ upstream of the river mouth, at altitudes of approximately 1,100 meters (Fig. 7). Such base level variations are not related to lithotype differences within the Serra Geral Formation. The anomalies between 70 and $60 \mathrm{~km}$ upstream the mouth are developed in rocks of the Gramado facies, whereas those between 30 and $20 \mathrm{~km}$ upstream are developed in rocks of the Paranapanema facies. However, as both facies correspond to the same lithotype (basalt) and share the same resistance to erosion, the knickpoints do not result from differential erosion. 

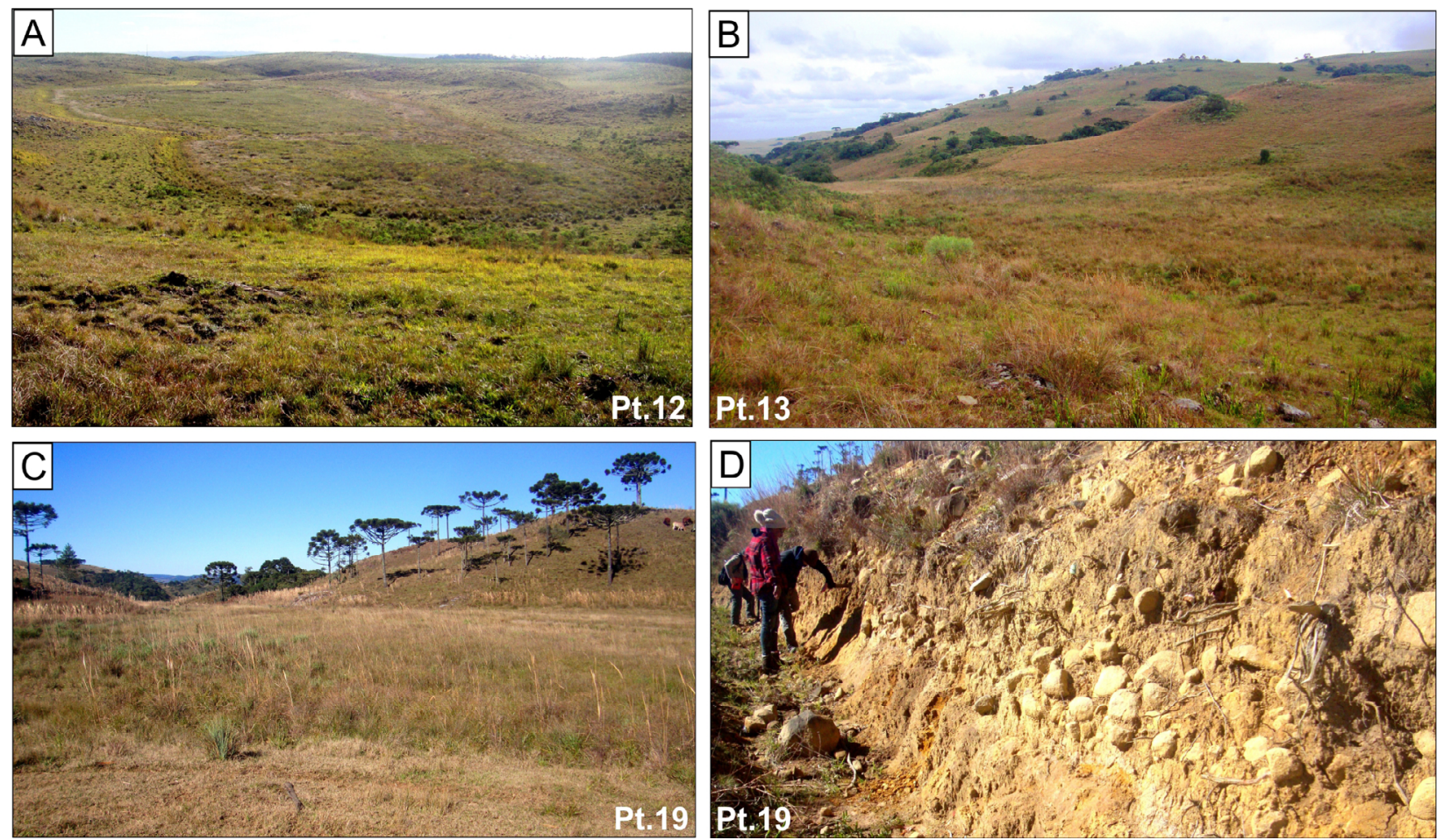

Figure 6. Pelotinhas catchment: (A and B) abandoned ponds on left-bank tributary headwaters, Area 2 (Fig. 4, Points 12 and 13); (C and D) abandoned fluvial deposits along the left bank of the catchment (Fig. 4, Point 19).

Knickpoints are present along right-bank tributaries, whose channels are shorter, and left-bank tributaries, where they occur near the headwaters and also along middle and lower segments of the Pelotinhas river (Area 3 - Fig. 4). Along Lajeado Quimera and Arvoredo creeks and other rightbank tributaries, the anomalies are found at altitudes between 1,100 and 850 meters i.e., not associated with any specific topographic level, which corroborates the fact they have not resulted from erosive processes, but from differential uplift, a situation observed in other areas by Wobus et al. (2006) and Burbank and Anderson (2012). The main anomalies follow a NE-SW-oriented lineament (white dashed lines in Fig. 7), which evidence structural control, as exemplified by the Lajeado do Arvoredo (Figs. 7B and 8) and Lajedo Quimera creek courses (Fig. 7C), along which knickpoints (to see Figs. 5A and 5B) align at distinct topographic levels with similar $30 \mathrm{~m}$ altimetric deviations (Figs. $7 \mathrm{~B}$ and $7 \mathrm{C}$ ). This direction coincides with the estimated direction of the Blumenau-Soledade Lineament.

Despite the presence of a knickpoint at the altitude of $850 \mathrm{~m}$ in " $\mathrm{d}$ " and at the altitude of $1,000 \mathrm{~m}$ in " $\mathrm{b}$ ", the longitudinal profiles of Barrocão (a) and Penteado (d) streams are convex. This may reflect distinct generations of knickpoints between these creeks. Showing practically the same altimetric deviations (30-40 m), channels upstream of the main slope break of the Pelotinhas river relate to the same base level. The difference is that channel "d" is located downstream of the anomaly. Drainage anomalies, channel abandonmen,t and other typical geomorphological features observed along the Pelotinhas river show the catchment is undergoing a reorganization process. Such reorganization takes place throughout the entire catchment area, but mainly along the main channel thalweg, which coincides with the Blumenau-Soledad Lineament.
The linear regression graphic of the main channel shows displaced line segments, which reflect ruptures of tectonic origin (Fig. 7C).

Along left-bank tributaries, a discrete similarity is observed in the distribution of knickpoints along a NE-SW structural trend at the catchment boundaries, also related to a topographic level, as are the anomalies near the headwaters (Figs. 7A and 7D).

\section{Structural analysis: lineaments}

The lineaments identified in the Pelotinhas catchment, that correspond mainly to negative relieflineaments associated to fractures (faults or joints) interpreted from major and minor structures (Figs. 8 and 9), are rectilinear and relatively homogeneous. Third and fourth order drainage segments according to Strahler (1945) classification are controlled by major lineaments, while minor lineaments mark first and second order segments strongly controlled by geological structures (Fig. $8 \mathrm{~B}$ ). The most prominent local lineaments are oriented N45E approximately, as is the Blumenau-Soledade Lineament, that divides the catchment into at least two relatively distinct domains of asymmetric slopes.

\section{Structural analysis: field structures}

Field-observed tectonic structures include faults and joints that are relatively similar in geometry. Rupture planes section primary structures such as centimeter to decimeter bands in rhyodacite and basalt. In rare occasions, faults intersect alteration structures such as spheroidal exfoliation, being thus considered relatively recent structures. The stereogram in Figure 8 represents main fault directions and deformation regimes. Nearly all faults are high-angle ones with dextral or sinistral kinematics, usually showing strike-slip or transtensional displacement. Faults and joints appear as single structures or conjugate 

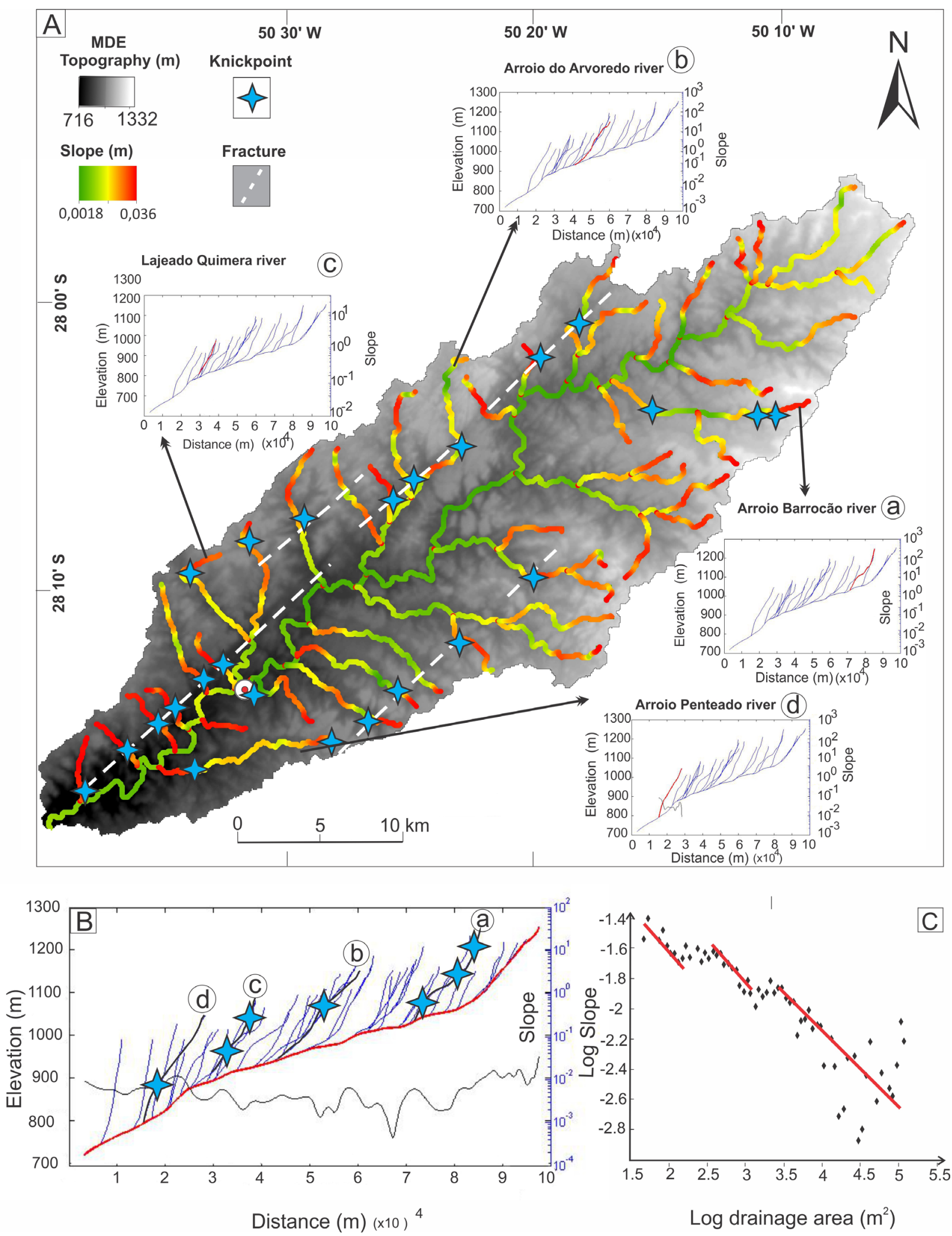

Figure 7. (A) Superposed distribution and lineament of major knickzones (red) across the Pelotinhas catchment and a DEM-SRTM. White dashed lines delimit areas of higher knickzone concentration. In the smaller boxes are longitudinal profiles of tributary (red) channels: (a) Barrocão, (b) Lageado do Arvoredo, (c) Chimera, and (d) Penteado. (B) Altimetric deviation relative from the predicted profile for the Pelotinhas river and its tributaries (in meters). The main knickpoints around Pelotinhas river and its tributaries are marked on the map by blue stars. (C) Linear regression chart, showing ruptures.

systems. Regardless of scale, the faults and joints observed at field resemble those photointerpreted from remote sensing imagery: the great majority of the structures are oriented between $30^{\circ}$ and $50^{\circ}(\mathrm{NE}-\mathrm{SW})$, fractures are mainly oriented NNE-SSW, NNW-SSE and less frequently ENE-WSW (Fig. 8).
The plume-like joints in Figure 9A occur at different scales, invariably in association with fracture (joints or faults) systems. Folds are rare, usually metric to metric, classified as horizontal-normal and, as in Figure 9B, associated with E-W compression approximately, as it will be discussed in the following sections. 


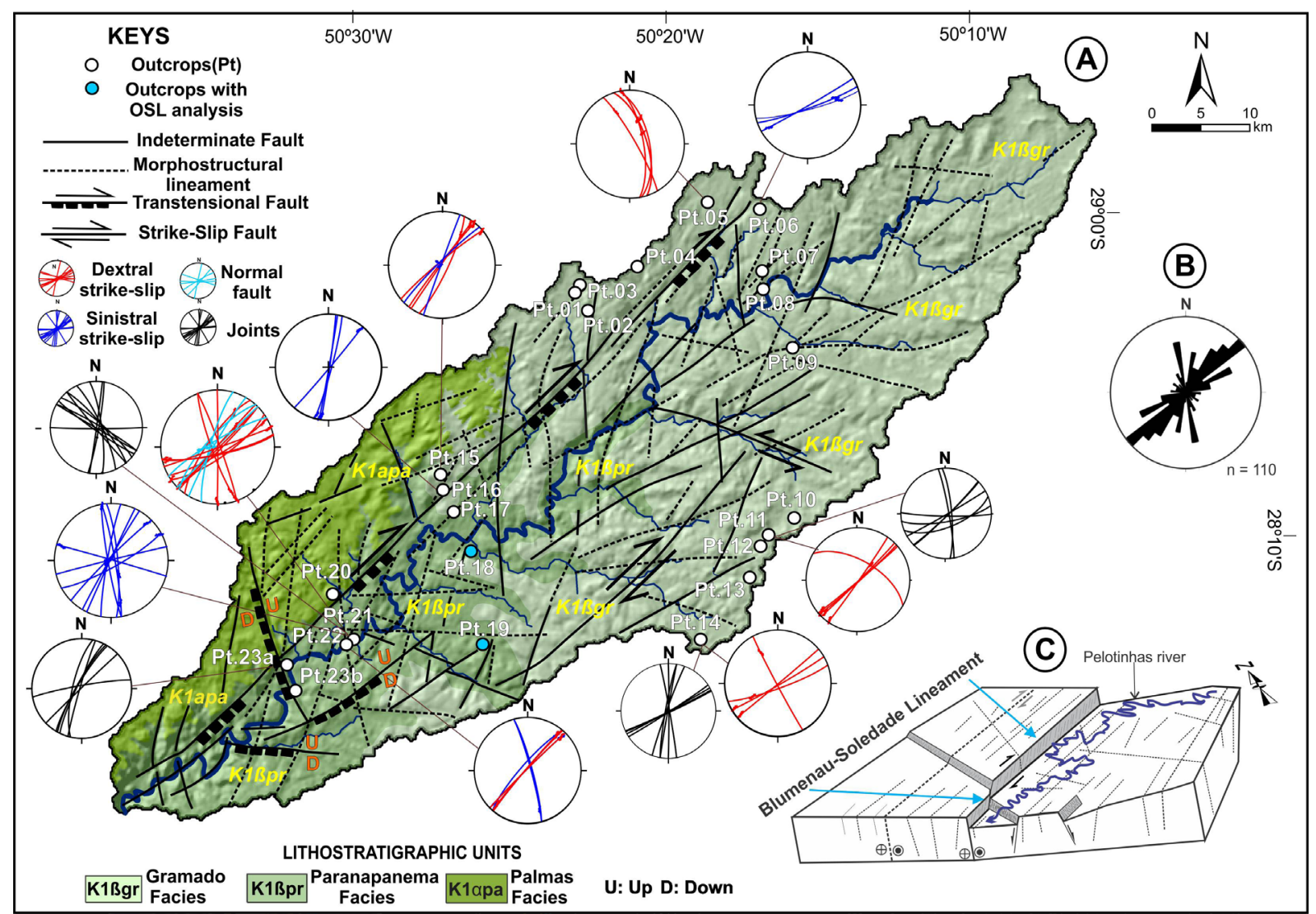

Figure 8. Photointerpreted structural lineaments across the Pelotinhas catchment, with field structural control. Blumenau-Soledade Lineament, the main fault controlling the Pelotinhas basin and the escarpment to its right banks mark the geological contact between Palmas and Paranapanema basaltic facies of the Serra Geral Formation. The faults are characterized by the presence of fracture planes with breccia, slickensides, and deformation of the planation surface.
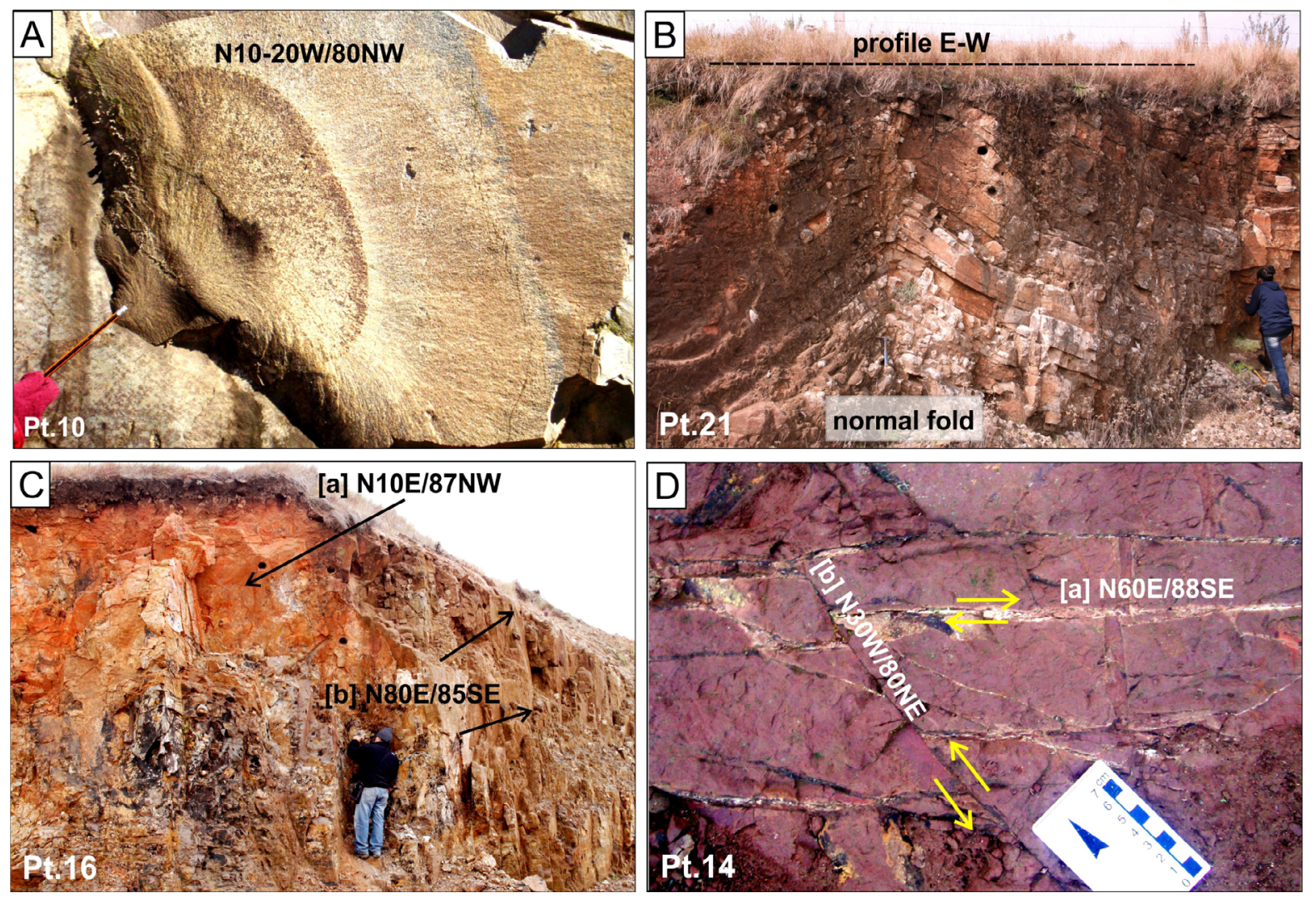

Figure 9. Brittle and brittle-ductile deformation structures in the study area: (A) plume-like joint in deformed basalt, N10-20W/80NW (Point 10); (B) metric open normal fold with azimuth N180/05 (Point 21); (C) intersection of strike-slip faults in [a] dense decimetric to metric N10E/85NW fault sectioned by a major N80E/85SE fault [b] metric to decametric dextral strike-slip fault (Point 16); (D) sinistral N30W/80NE fault [b] cutting dextral N60E/88SE strike-slip fault [a] (Point 14), plan view. 
Intersection of decametric (Fig. 9C) to centimetric (Fig. 9D) faults are very common, with slickensided fault planes in various directions, with a hierarchy based on the displacement of fault planes by more recent ones. Therefore, the existing geological structures indicate that different paleostress fields took part in the deformation history of the study area.

Fault zones are heterogeneous, with structures up to tens of meters wide. The NW-SE- and NNW-SSE-oriented structures are mostly decametric, while those oriented NE-SW and
NNE-SSW vary from metric to hectometric, as observed in the field work. In rare cases, they are kilometric, as determined from photointerpretation.

Damage zones are well formed in fault planes, mainly in the northwestern portion of the study area, where hectometric brittle shear zones are present. Structures are planar, in some cases curviplanar with invariably high, even vertical dip angles (Figs. 10A-10D). Planes are usually smooth and polished. In rhyodacites, planes are filled with veins of oxides or
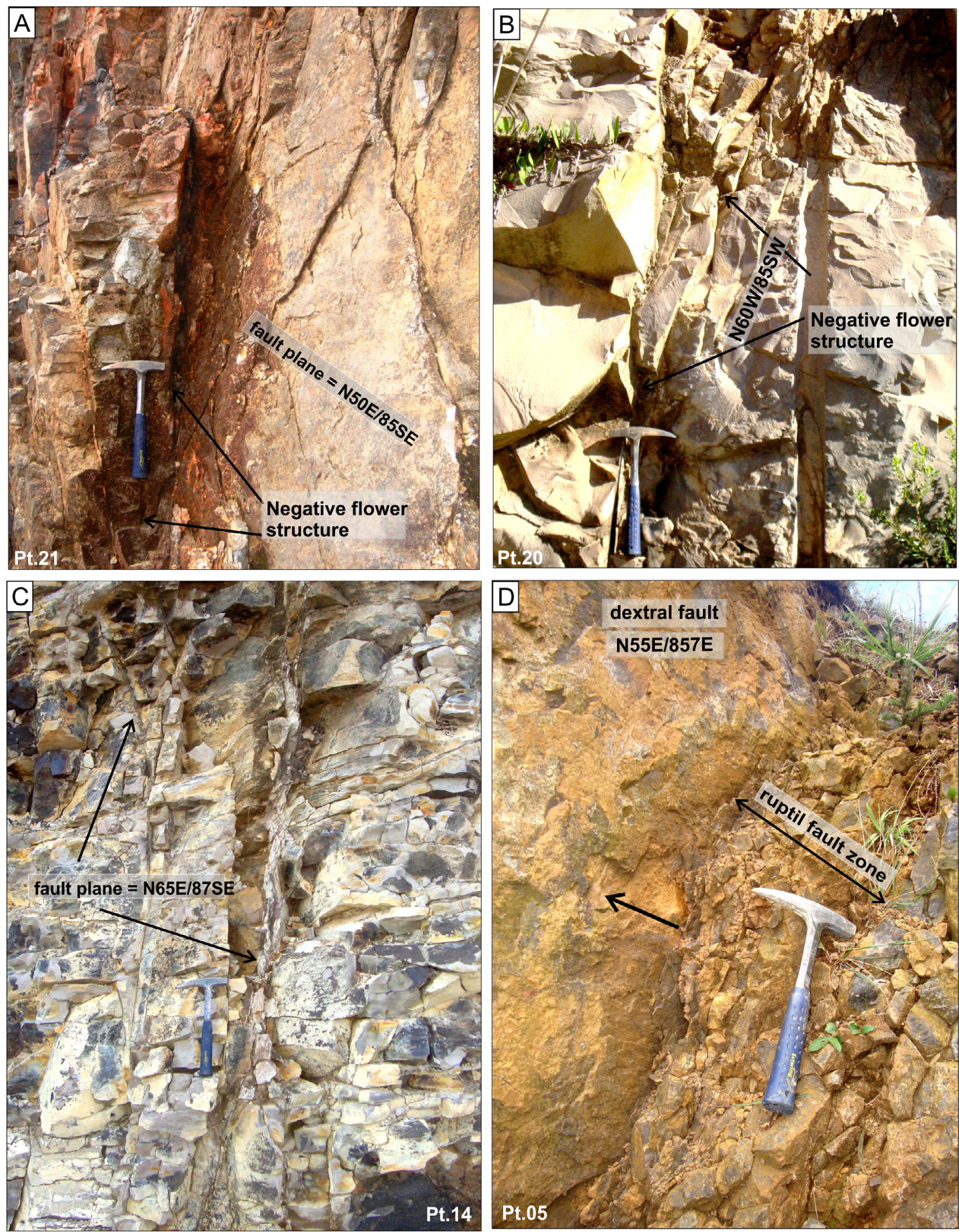

Figure 10. Fault planes typically found in the study area: (A) dextralN50E/85SE strike-slip plane with fault breccia (Point 21); (B) transtensional N60W/85SW negative flower structure in massive basalt (Point 20); (C) Breccia zone in carbonate-filled dextral N65E/87SE strike-slip fault (Point 14); (D) Breccia in dextral N55E/85SE strike-slip fault in weathered basalt (Point 5). See description points in Figure 8. 
clay-minerals (Fig. 11). In basalts, planes are filled with calcite or zeolite; damage zones vary, with centimetric to metric bands of fault breccia (Fig. 11A), sparse crush breccias, and rare protoclasites.

The faults, formed under brittle strike-slip or transtensional shearing, are marked by the presence of low-dipping millimetric to centimetric slickensides and steps (Figs. 11B-11D). The slickensides are visible in fractures filled with oxides or calcite and less noticeable in non-mineralized faults. The field readings in Figures 9 to 11 refer to strike-slip faults whose statistically more persistent N30-50E orientations coincide with that of the Blumenau-Soledade Lineament.

However, some representative yet non-penetrative families of strike-slip faults are oriented N10-20W, N10E and N6070E. The two main orientations, NE-SW and NNW-SSE, are indicated in almost all outcrops where metric and decametric fault planes are present. NW-SE lineaments are of modest occurrence, being observed mainly at outcrop scale.

The geometric, kinematic, and dynamic aspects of structures found in the Pelotinhas catchment were analyzed. The kinematically compatible fault systems are shown by tectonic pulse in Figure 12. The figure shows three compressive pulses, responsible for the generation of strike-slip and transtensional faults, intercalated to an extensional pulse, responsible for the generation of normal faults.

Fault kinematics was determined from the spatial orientation of fault steps, slickensides and slickenlines formed by mineral growth (Figs. 11B-11D), and other indicators such as spoon-shaped depression and chatter marks, as well as $\mathrm{R}$ conjugate rupture planes of Petit (1987) and Doblas (1998) (Fig. 11C). Normal faults are sparse, usually oriented NNW-SSE and NNE-SSW, respectively, with moderate to high dip angles.

The NE-SW compression and its corresponding NW-SE distension are associated with the first compressional tectonic pulse interpreted to have affected the area, which caused nucleation of reverse and dextral strike-slip faults, both groups of structures oriented NNW-SSE (Fig. 12A). The same tectonic pulse reactivated NE-SW lineaments as $\mathrm{T}$ fractures of Riedel and NW-SE lineament as dextral transtensional fault. After that, there is a pulse with a subvertical paleostress field (Fig. 12B) that causes extensional deformation, responsible for moderate to high dip normal faults and down-dip reactivation of NE-SW faults.

A second, compressional tectonic pulse oriented between NNE-SSW and NNW-SSE, around N-S field paleostress and its corresponding E-W to WNW-ESE oriented extension, reactivated old strike-slip faults as a family of sinistral transtensional and transpressional NE-SW open, high angle faults with clay-mineral filled planes that almost always show sinistral faults (Fig. 12C). Such faults locally section NNW-SSE structures, which eventually show dextral kinematics.

A third, current compressional tectonic pulse is represented by a stress field oriented between E-W and WNW-ESE, with an extension oriented between N-S and NNE-SSW (Fig. 12D),
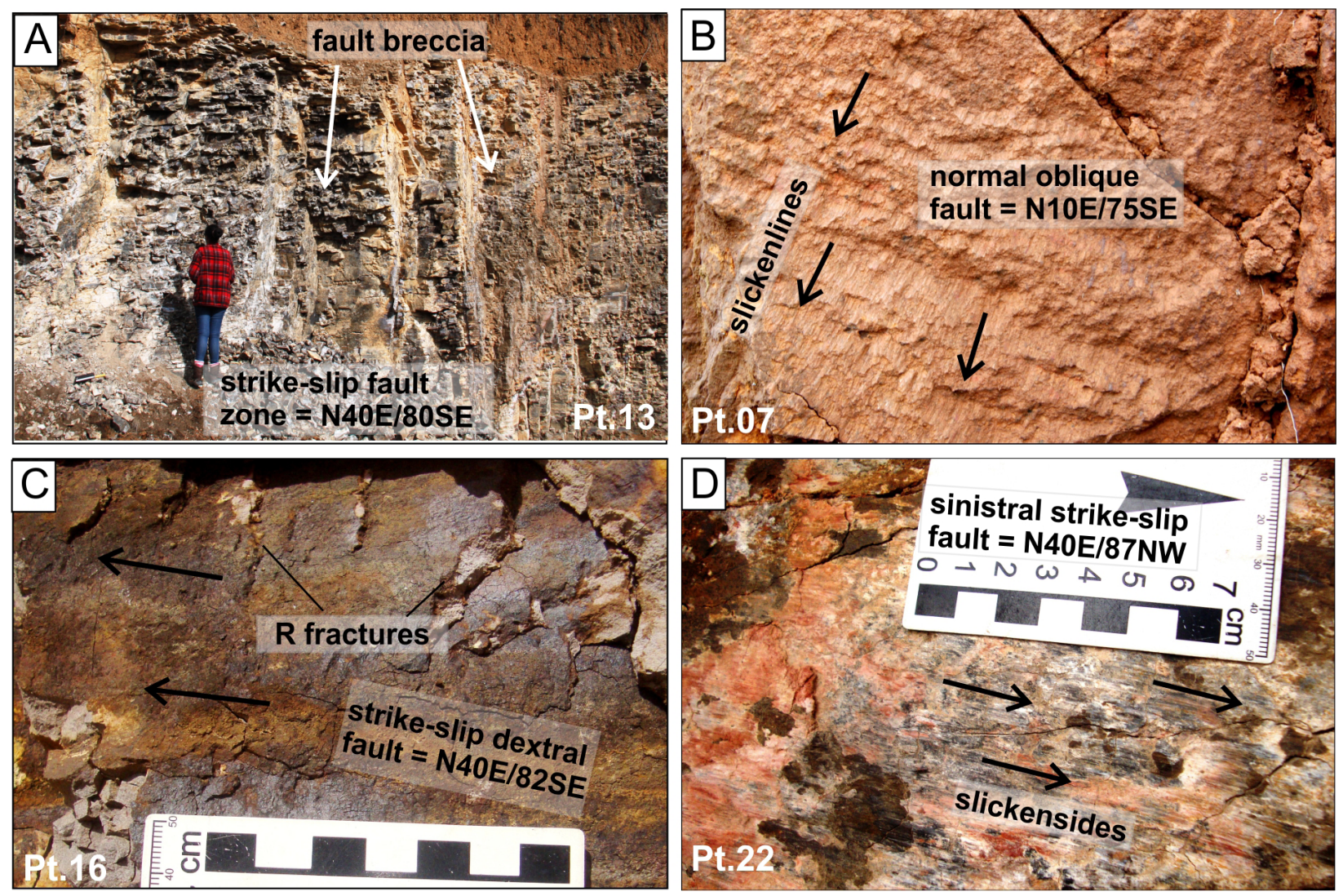

Figure 11. Representative structural elements of regional deformation (black arrows indicating missing block kinematics): (A) breccia zone in rhyodacite dextral N40E/80SE strike-slip fault (Point 13); (B) normal-oblique N10E/75SE fault with N146/58 steps and slickenlines (Point 7); (C) rough dextral N40E/82SE strike-slip fault plane with associated N55E/80SE R fractures (Point 12); (D) sinistral N40E/87NW strike-slip fault plan with N45/15 slickensides in clay-minerals and oxides (Point 22). 

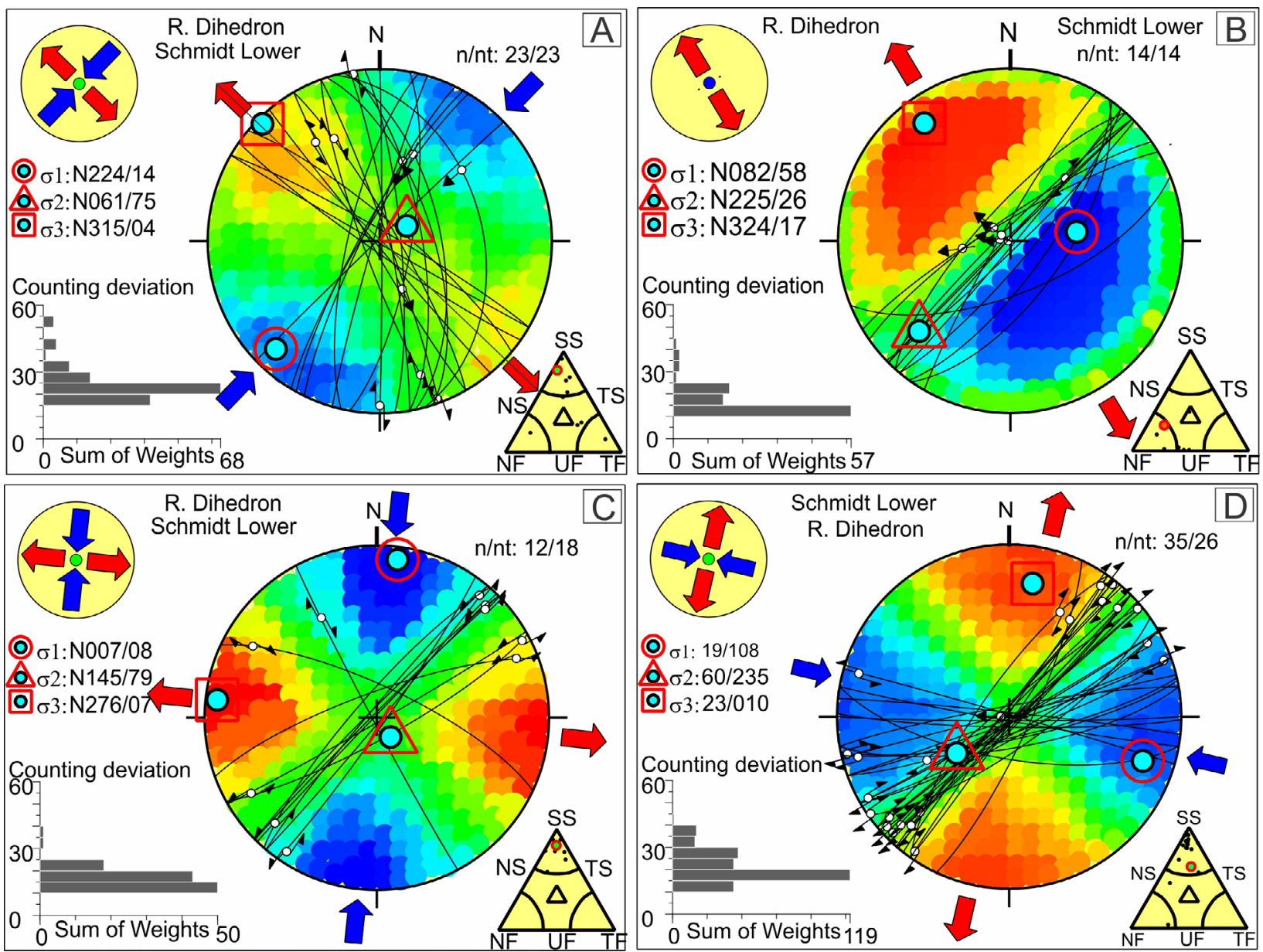

SS: strike-slip; NF: normal fault.

Figure 12. Paleostress diagrams obtained from selected field-observed faults. The sequence of diagrams follows a possible relative chronology of deformation pulses, from older to younger: (A) D1 compression; (B) D1' extension; (C) D2 compression; (D) D3 compression.

responsible for approximately E-WT-joints and discrete NW-SE fractures and dextral E-W and WNW-ESE faults. NNW-SSE faults reactivated or nucleated with sinistral kinematics would also be related to this pulse, but NE-SW faults are reactivated with dextral kinematics, that are the ones that mainly control the current morphotectonics (Fig. 8C).

\section{DISCUSSION}

\section{General aspects}

The geometric-kinematic analysis of the faults in the Pelotinhas catchment was intended to identify paleostress fields associated with the existing brittle structures and, based on their spatial correlations, the establishment of a relative chronology of deformation pulses. The geometric arrangements among fault families (Figs. 10 and 11) imply superposition of deformation events nucleating new faults and probably reactivating basement ones represented by the Blumenau-Soledade Lineament.

Considering that tectonic deformation rates are very low in intraplate environments, the elements of local tectonic geomorphology are of very complex characterization, requiring study of the correlations among morphostructures and the characterization of a tectono-structural framework of regional geological units.
One of the premises that guide intraplate studies in South America is that such environments are stable enough for geomorphological modifications to be due only to tropical climate processes.

However, in accordance with authors such as Riccomini et al. (1989) and Hasui (1990) and seismological meta-analyses (Assumpção 1992, Assumpção et al. 2014, Agurto-Detzel et al. 2017) carried out based on the hypothesis that earthquakes are more frequent in shallow, warmer zones, we argue that considering tropical climatic processes as the sole controllers of geomorphological changes in intraplate regions would be a simplistic approach. Yet, fault activity records might be insufficient to support neotectonic investigations, especially in sites where intraplate stress is accommodated by reactivation of preexisting faults with kinematics that is different from that expected for the currently active stress field.

Understanding the landscape-reflected deformation of the study area depends on understanding the structural and morphotectonic processes discussed below.

\section{Morphotectonics}

Our working hypothesis is that both transtensional and extensional faults form a structural network that controls the evolution of the local landscape, reorganizing the drainage system which causes the dismantling of the local erosion 
surface (Pd3 - see Fig. 1). According to several interpretations (Bigarella et al. 1965, Valadão 2009, Kröhling et al. 2011), if the planation surface remained stable until the early Paleogene, then the faults were intermittently active along the Cenozoic, causing deformation of the physical landscape and shaping the current framework of morphostructures, which characterizes a morphotectonic process.

Faults form the escarpment on the right bank of the Pelotinhas catchment (Fig. 4-profiles) are associated with drainage network anomalies, patterns and orientations, and also narrow canyons of varied depths (Fig. 5). Faults also promote abandonment of channels as they caused westward tilting of the basin (Fig. 6). Fracture-related knickpoints indicate tectonic control on slope breaks, being possibly related to poorly adjusted channels characterized by longitudinal profile ruptures. When applied to the drainage system, the tectonically imposed modifications are perceived as changes in the pattern and shape of the channels, the first elements to respond to crustal deformation (Schumm 1986, Keller and Pinter 2002, Bull 2007, Burbank and Anderson 2012).

Most channels in the Pelotinhas catchment are controlled by fault valleys, like the Pelotinhas itself, a subsequent river that migrated to the base of a fault escarpment, probably due to rapid avulsion. Near the middle and lower courses, channels conform to the morphological reorganization that formed knickpoints in longitudinal profiles (Fig. 7). These morphostructures are interpreted as resulting from subtle but recurrent intraplate tectonic movement combined with climate-induced sculpting of landforms (Fig. 4).

Geomorphometric information shows that the local drainage network is still being reorganized, given the relatively recent differential block uplift and subsidence, one of the main consequences being the formation of an escarpment in the catchment area. The fast uplift also controls the pedological characteristics of the region, where well-developed soils are practically nonexistent. Neosols — or litolical soils — are broadly predominant, followed by thin gleysol or organosol pockets in the upper and middle courses of the Pelotinhas river. Tilting of the catchment area causes the observed drainage asymmetry and its consequent drainage pattern changes, from dendritic at the headwaters to trellised in areas more intensely controlled by faults, more specifically on the rightbank catchment areas.

Abandonment of channels, meanders and ponds at headwaters of left-bank tributaries (Fig. 6) are also evidence of recent reorganization, characterizing a relatively new local dissection process, active probably from the Pleistocene onwards (Tab. 1). This hypothesis is based on the low surface roughness of the area, the low thickness of soil beds, the lack of extensive correlative deposits, and the presence of knickpoints and knickzones associated with lineaments. Such features attest that the dissection caused by the incision of the drainage channels in large parts of the catchment is in its initial phase.

Lineaments mark slope ruptures characterized as knickpoints or knickzones where they cut or coincide with longitudinal profiles of drainage channels (Figs. 5A-5C and 7). These anomalies normally cause base level drop and longitudinal profile imbalance, like those observed by Santos et al. (2019) in neighboring catchments affected by important faults (Pelotas and Lava-Tudo), and also by Val et al. (2013) in the Amazon. In the Pelotinhas catchment, the distribution of knickpoints along the right bank is associated with the NE-SW escarpment front. According to Burbank and Anderson (2012), such features evidence tectonic control of drainage networks as they separate areas of high and low uplift rates or, locally, footwall and hanging wall blocks along fault zones. The development of knickpoints due to erosion (topographic gradient) requires constant migration rates (Wobus et al. 2006), which, in the Pelotinhas river, only occur at the headwaters, at altitudes higher than $1,000 \mathrm{~m}$.

Tilting of the planation surface across which the Pelotinhas river flows is evidenced by its catchment asymmetry factor, which, although being heterogeneous along the major axis, indicates that the area occupied by the right bank is smaller than the left bank. Tilting is also responsible for drainage pattern anomalies, given the presence of paleochannels and, especially, fault-associated knickpoints. On the other hand, a young age is suggested for the escarpment based on its relatively fair preservation to the west of the main channel. The deeper incision in the lower third of the Pelotinhas suggests a differential uplift that forces the main channel to adjust to the escarpment base. The OSL data, although specific, shows the process of adjusting the drainage system in the last $15 \mathrm{k}$ years, the result of which is consistent with the processes of abandoning channels noticed in the low course, where there is asymmetry of the basin.

Altimetric deviation in the Pelotinhas catchment indicates that the system is in disequilibrium. The main knickpoint (Fig. 7) represents a transient response of the main channel and its tributaries to the advanced erosion upstream toward equilibrium. This results in knickpoint retreat from the same base level. Additionally, the lineament of these anomalies in the right banks of the catchment reflects structural control of the substrate, differently than in the left banks, where progressive erosion causes the knickpoints. The elongation ratio (0.50) corroborates the disequilibrium state of the catchment, the lack of organization of the drainage system being due to the local morphotectonic evolution.

Tilted steep areas are mainly associated with the NE-SW fault system, as shown in the geological-structural map of Figure 8. Such an association reinforces the hypothesis of tectonic control of the current morphology of the Pelotinhas catchment, exerted mainly by the Blumenau-Soledade Lineament.

The morphotectonic evolution of the Pelotinhas catchment is also recorded at an intersection of faults systems, where morphological features such as abandoned channels and collapse of small blocks are present.

\section{Tectonics}

The main fault and joint trend characterized in the field is oriented NE-SW. Less persistent secondary trends are oriented NNE-SSW, NNW-SSE, and E-W (Fig. 8).

The NE-SW, NNE-SSW, NW-SE and WNW-ESE fault planes (Figs. 9 to 11) coincide with morphostructural lineaments 
identified in satellite imagery and digital elevation models. They influence the morphometric characteristics of the terrain as they control drainage segments and delimit the main escarpment formed by the Pelotinhas river and its direct tributaries (Fig. 8).

The NE-SW faults were nucleated under sinistral transtensional regime. Later, they were reactivated as dextral faults, which corroborates the fact that the deformation pulses derived from distinct paleostress fields. Transtension is characterized by concomitant formation of directional and oblique-dipping striae (Figs. 11A-11C). As the structural framework of the Proterozoic basement of the Paraná Basin is represented by NE-SW faults (e.g., the Blumenau-Soledade Lineament) and others following the regional tectonic framework (Zalán et al. 1990, Soares et al. 2007), reactivated as a dextral transtensional fault oriented N30-40E (Figs. 11A-11C).

The NNE-SSW, NNW-SSE, N-S and E-W structures also identified in the field, on the other hand, do not seem to be associated with older rupture planes, being interpreted as aseismic faults probably nucleated from the Paleogene.

The paleostress components of the Pelotinhas catchment area (Fig. 12) were established from structural data on different fault families. The fault systems characterize the positional alternation of the maximum horizontal stress component $(\sigma 1)$ and the minimum horizontal stress component $(\sigma 3)$ during the Cenozoic, which allows for the identification of three distinct compressive stress pulses, very similar to those found by Santos et al. (2019) in a nearby research area. In addition to these pulses, there is also an extensional pulse that characterizes local reduction of compressional paleostress.

Slickensided fault plane data and superposition of structures were decisive in the interpretation of the hierarchy of deformation pulses in Table 2. The observations are consistent with previous meta-analyses presented by Silva and Mello (2011) on the Cenozoic tectonics and paleostress history of southeast and southern Brazil.

However, the chronology of local deformation pulses is still relative, based on both observation of fault intersections and comparative tectonic analysis between the Pelotinhas catchment and nearby areas in southern Brazil. The geochronological determination of rocks in the northern portion of the study area (Serra Geral Group domains) (Noblet et al. 1996) was indirect, based on apatite fission track analysis (AFT). The above-mentioned authors interpreted the NW-SE reactivation of the São Jerônimo-Curiúva fault zone as compatible with the main orogenic phases experimented by the Andes (Peruvian, 90-75 Ma; Incaic, 50-40 Ma; and Quechuan, 17-5 Ma). At the local scale, intraplate AFT studies of the southeast coast and central north parts of southern Brazil identified Upper Cretaceous ( $80 \mathrm{Ma})$, Paleocene $(\sim 60 \mathrm{Ma})$, Oligocene $\sim 40 \mathrm{Ma})$, Neogene $(\sim 25 \mathrm{Ma})$, and Plio-Pleistocene $(\sim 10 \mathrm{Ma})$ tectonic pulse records (Hadler et al. 2001). A 17 Ma tectonic pulse was also characterized along the axis of the Ponta Grossa Arch (Franco-Magalhães et al. 2010a, 2010b). Also, thermochronological studies evidenced at least two cooling events related to the morphotectonic framework of topography forms in south and southeastern Brazil (Modica and Brush 2004, Cogné et al. 2011, Siqueira-Ribeiro et al. 2011).

The exhumation of the Ponta Grossa Arch and the subsequent reactivation of faults approximately $20 \mathrm{Ma}$ ago are corroborated by Franco et al. (2005) and Franco-Magalhães et al. (2010a, 2010b), and also based on AFT data. However, based on cosmogenic dating of $\mathrm{Be}^{10}$, Sordi et al. (2018) argue that the plateau where the headwaters of the Pelotas River and its tributary, the Pelotinhas river, are located has experienced some stability over the last $30 \mathrm{Ma}$, as verified by Gallagher et al. (1995) in view of the local flexural strength.

However, based on field geological-structural data, our studies show that such stability can only be considered for occasional normal faults, that is, blocks with predominantly vertical or high angle displacement, but not for faults nucleated under directional regimes (Figs. 9 to 11 ). In this sense, Karl et al. (2013), Oliveira et al. (2016), and Oliveira and Jelinek (2017) verified reactivation of high-angle fault blocks in response to intraplate stress, mainly between the Paleogene and the Neogene. If the study area had been experiencing stability, relatively symmetrical smaller catchments would be expected, with less structured patterns (e.g., dendritic). However, this is not the case in the Pelotinhas catchment, which is asymmetric, notably elongated and strongly structured (Fig. 4).

Regarding the multiple deformational pulses that affected the study area, our interpretation is that the oldest paleostress

Table 2. Relative chronology of deformation pulses in the Pelotinhas catchment.

\begin{tabular}{|c|c|c|c|c|c|}
\hline $\begin{array}{l}\text { Estimated } \\
\text { period }\end{array}$ & $\begin{array}{l}\text { Deformation } \\
\text { pulses }\end{array}$ & $\sigma 1$ & $\sigma 3$ & $\begin{array}{l}\text { Paleostress fields } \\
\text { (geologic-structural data }\end{array}$ & Observations \\
\hline $\begin{array}{l}\text { Pleistocene to } \\
\text { Holocene }\end{array}$ & $\begin{array}{c}\mathrm{D} 3 \\
\text { (compressive) }\end{array}$ & $\begin{array}{c}\text { WNW-ESE to } \\
\text { NW-SE }\end{array}$ & $\begin{array}{l}\text { NNE-SSW to } \\
\text { NE-SW }\end{array}$ & & $\begin{array}{l}\text { pure extension can be } \\
\text { found locally }\end{array}$ \\
\hline $\begin{array}{l}\text { Miocene } \\
\text { to Pleistocene }\end{array}$ & $\begin{array}{c}\mathrm{D} 2 \\
\text { (compressive) }\end{array}$ & NNW-SSE & NNE-SSW & & $\begin{array}{l}\text { found as the most recent } \\
\text { pulse at some points }\end{array}$ \\
\hline $\begin{array}{l}\text { Paleocene to } \\
\text { Miocene }\end{array}$ & $\begin{array}{c}\text { D1 } \\
\text { (compressive) to } \\
\text { D1' (extensive) }\end{array}$ & $\begin{array}{l}\text { NE-SW } \\
\text { to Vertica }\end{array}$ & NW-SE & & $\begin{array}{l}\text { compressive pulse that } \\
\text { evolved to extensive }\end{array}$ \\
\hline
\end{tabular}


event (D1), probably the first one to cause deformation of the local erosion surface ( $\mathrm{Pd} 3$ ), took place between the Paleocene and the Eocene (Fig. 12A, Tab. 2), given that records of its activity in other areas of south and southeastern Brazil show similar geological-structural characteristics, but in a more readily established chronology of events (Riccomini 1995, Salvador and Riccomini 1995, Roldan et al. 2010, Morales et al. 2016). In this first deformational pulse, local compression is oriented NE-SW, while distension is oriented NW-SE, resulting in dextral strike-slip and reverse faulting, both oriented NNWSSE (Fig. 12A), and reactivation of basement NE-SW faults as tensional fractures.

Although the NE-SW compressive pulse remained active from the Paleogene to the early Neogene, an intermediate extensional pulse (D1') may have been active between the Eocene and the Miocene. Its maximum paleostress axis would follow the SV vertical (Fig. 12B, Tab. 2) that activated NE-SW normal fault planes with down-dip kinematics, also generating normal and normal-oblique, moderate to high dip angle NNE-SS faults (Fig. 12B). Such a tectonic pulse in early Paleogene is in accordance with studies of other areas (Campanha et al. 1985, Peyerl et al., 2018), being considered by us a relief of compressive stress with predominant $\sigma_{3}$ extension in the same direction as the Cenozoic initial compression. In southern Argentina, Foix et al. (2012) demonstrate a frank extensional pulse in the San Jorge Gulf basin between the Cretaceous and the Paleocene.

Later in the deformational history of the Pelotinhas catchment, we interpret a second compressive pulse (D2) with $\sigma_{1}$ paleostress orientation between NNE-SSW and NNW-SSE. The orientation of the $\sigma_{3}$ axis, in turn, ranges from WNW-ESSE to ENE-WSW (Fig. 12C, Tab. 2). This event is related to the Plio-Pleistocene deformation of areas such as the Bauru Basin (Fernandes and Coimbra 1996), the initial deformation of the Lajes Dome to the North of the study area (Fig. 2) (Jacques et al. 2014), and the Paleogene deformation of the Curitiba Basin (Chavez-Kus and Salamuni 2008). The NE-SW faults reactivated or generated in this pulse are essentially strike-slip and high-dip transtensional in nature, with dextral kinematics (Figs. 11B-11C).

The third deformation pulse (D3, Tab. 2), active probably since the Pleistocene and, therefore, neotectonic, is characterized by regional stress with $\sigma_{1}$ and $\sigma_{3}$ oriented WNWESE and NNE-SSW, respectively (Fig. 12D). Preexisting N-S joints have been reactivated as sinistral shear joints, discrete sinistral NW-SE shear joints, and also dextral E-W faults. Sinistral NNW-SSE faults would also have been nucleated in the same pulse. In contrast, sinistral ENE-WSW and NE-SW strike-slip and transtensional faults begin to show dextral kinematics in a large number of outcrops. The diagram in Figure 12D shows the geometry and kinematics of these structures, which in dynamic analysis would characterize compressive stress oriented approximately between NW-SE and WNW-ESSE. Thus, our interpretation is that the landscape changes in the Pelotinhas catchment area are associated with directional deformation caused by a stress event of mean E-W direction, currently affecting the South American
Plate (Assumpção 1998), with local field variations between WNW-ESE and ENE-WSW.

\section{Regional implications}

The approximately E-W stress active in the study area since the Late Pleistocene has been addressed not only in fault dynamics and kinematics studies (Salvador and Riccomini 1995, Jacques et al. 2015, Morales et al. 2016, Peyerl et al. 2018, Santos et al. 2019), but also in studies of intraplate seismicity (Assumpção 1992, Coblentz and Richardson 1996, Marotta et al. 2013, Assumpção et al. 2014). At broader scales, studies carried out from Ecuador to northern Chile along the Andes confirm neotectonic episodes within the South American Plate (Lavenu 2006). There, the main acting stress shows maximum compression in a dominant stress field along an approximately E-W axis active from the Miocene to the Quaternary (Allmendinger and Gonzalez, 2010) or over the last $9 \mathrm{Ma}$ (Lavenu and Cembrano 2008).

The maximum stress directions presently active in the study area are defined by a field oriented between E-W to WNW-ESE (D3 in Tab. 2), a fact corroborated by Lavenu and Cembrano (2008) and Giambiagi et al. (2016), determining a maximum stress field in Argentine and Chilean segments of the Andes whose orientations are compatible with the situation presented herein, with local variations to N-S. In some areas of the Pelotinhas catchment, the only observed deformation corresponds to a NNE-SSW paleostress field, as shown in Figure 8 (Point 16). Lithological differences between lava flows of Palmas and Paranapanema facies and the relative complexity of the structural framework inherited from the Proterozoic basement probably mark the local rheological behavior and, consequently, specifically different responses to stress.

Understanding the development of different maximum stress orientations in the study area over a relatively short period of time requires comprehensive analysis of the tectonic changes experienced by the Brazilian platform. A similar physical behavior was reported (Sébrier et al. 1988, Giambiagi et al.2016) in the Altiplano-Puna region of the Central Andes, where evidence accounts for at least four distinct main stress axis alternations related to the interaction of the Nazca and South American plates and intrinsic or local rheological factors since the Middle Miocene. The paleostress events verified there indicate prevalence of different tectonic regimes, from compressional to extensional including directional (strike-slip and transpressional) ones.

Our interpretation for the study area points to a variable paleostress causing alternation of the main fault, the Blumenau-Soledade Lineament, from strike-slip/transtensional to extensional and then back to transtensional kinematics. However, as the local evolution involves nucleation or reactivation of different faulting directions with discrepant kinematics, we consider, in consonance with the authors mentioned, that the paleostress events assumed different directions until being stabilized along the current one between E-W and WNW-ESE (Tab. 2). 


\section{CONCLUSIONS}

The catchment area of the Pelotinhas river, located on the São Joaquim plateau, extends exclusively over basalts and rhyodacites of the Serra Geral Group, a province of volcanic rocks in the Paraná-Etendeka Large Igneous Province. Prior to the establishment of the catchment area and, therefore, the dissection of the region, remnants of a large pediplane ( $\mathrm{Pd} 3)$ prevailed in the location. To evaluate the hypothesis of tectonic deformation for the local landscape, different geomorphometric parameters (drainage patterns and anomalies, catchment asymmetry, knickpoints and knickzones) were analyzed from river equilibrium profiles and structural lineaments. Correlation of geomorphometric, photointerpretation and field-collected tectonic data allowed successive Cenozoic deformation pulses. The relative chronology of pulses, in turn, was interpreted from a correlation of the area with analogous ones in southern and southeastern Brazil and other areas at similar latitudes along the Andes.

The valleys of the Pelotinhas river and its parallel tributaries, as well as the adjacent escarpment, resulted from morphotectonic processes controlled by the basement transtensional NE-SW Blumenau-Soledade Lineament, reactivated by the paleostress fields determined in the present study. Conjugate or not to the lineament, minor faults oriented ENE-WSW, N-S, and NNW-SSE control and compartmentalize parts of the drainage network. The structural framework deformed the surface of the terrain during the Cenozoic, characterizing morphostructures that, associated with climatic erosive processes, control the local geological and geomorphological evolution. The most intense deformation, active from the Pleistocene onwards, modifies the local physical landscape.

The strong morphotectonic character of the local features is revealed by the presence of abandoned channels, ephemeral ponds, tilting of the erosive surface, drainage pattern changes, relatively extensive escarpments, knickpoints and knickzones and, regionally, the Pelotinhas catchment asymmetry. The main morphostructures are related to tectonic lineaments, most of them bearing evidence of dextral or sinistral strike-slip and transtensional faulting.

Kinematic indicators of fault planes and superposition of joints and faults allow for the interpretation of at least three deformation pulses: (D1) the oldest, Paleocene to
Eocene, with NE-SW paleostress and NW-SE extension, which reactivated dextral strike-slip basement faults; (D1') still in the same pulse, vertical or sub-vertical paleostress, causing moderate-to-high-angle down-dip reactivation of NE-SW faults with normal or oblique-normal block displacement; (D2) marked by NNW-SSE paleostress and ENE-WSW extension, with sinistral and dextral reactivation of NE-SW and NW-SE faults, respectively; and (D3) compressional to WNW-ESE and extensional to NNESSW causing sinistral and dextral reactivation of NNWSSE and NE-SW faults, respectively, and ENE-WSW fault nucleation as well.

Considering that the pediplane $(\mathrm{Pd} 3)$ is a surface that remained stable in part of the Paleogene (Oliveira et al. 2016, Sordi et al.2018), we conclude that the beginning of its local incision and the dismantling resulted in successive changes in regional tectonic stress.

The hypothesis presented herein is that tectonic landscape deformation has been taking place since the Paleocene or Eocene to at least the late Pleistocene in response to slow, usually aseismic processes. We conclude, however, that the Blumenau-Soledade Lineament has been reactivated as a dextral transtensional fault since the installation of the neotectonic regime in the Pleistocene that largely shapes the most prominent morphostructures of the Pelotinhas catchment (river control, drainage anomalies, abandoned channels, differential dissection, escarpment, knickpoint control, tilting and rotation of smaller blocks, and differential roughness), allowing our interpretation that the catchment has evolved from both morphotectonic and morphoclimatic processes.

\section{ACKNOWLEDGMENTS}

We are grateful to Universidade Federal do Paraná (UFPR) and Universidade Federal Rural do Rio de Janeiro (UFRRJ), especially their post-graduate program in Geology, for having provided material support in the present study. We are also grateful to the Dating and Dosimetry Laboratory of Universidade Federal de São Paulo (UNIFESP) and its coordinator, Professor Sonia H. Tatumi, for helping us with OSL dating. The research was carried out with the support of CNPQ PQ-2 research grant, Process 307738 / 2019-1.

\section{ARTICLE INFORMATION}

Manuscript ID: 20200080. Received on: 08/02/2020. Approved on: 07/22/2021.

ES: hypothesis discussion; field work planning and subsequent field data collection; analysis of structural data; preparation of figures 5, 6, $8,9,10,11,12$, and table 2; preparation of the initial manuscript and subsequent corrections in the English version, mainly in the writing of results and discussions; preparing files for submission; follow-up reviews. C.L.S.: discussion of the hypothesis; field data survey; data collection for LOE analysis; morphostructural analysis of data; writing of chapters 3 and 4.1; making of figures 4 and 7; writing part of the manuscript; manuscript revision after the English version. E.R.N.: discussion of the hypothesis; field data survey; analysis of morphometric data, preparation of figures 2 and 3; review of figure 8; general text review; preparation of chapter 5.2 about morphotectonics; manuscript revision in Portuguese. J.M.S.: writing of chapter 2; field data collection; making of figure 1; bibliographic survey; forwarding of sediment samples for LOE analysis; analysis of LOE results; creation of table 1; review of figures 3, 4, and 7. W.R.L.P.: general review of structural and tectonic analysis; review of figures 5, 9, 10, 11, 12 and table 2. Final review of the text and references. V.B.G.: preliminary version in English; general review of the text with analysis of data consistency with the figures and text; verification of citations of figures and bibliographies; revision of chapter 5 about tectonic analysis.

Competing interests: The authors declare no competing interests. 


\section{REFERENCES}

Agurto-Detzel H., Assumpção M., Bianchi M., Pirchiner M. 2017. Intraplate seismicity in mid-plate South America: correlations with geophysical lithospheric parameters. In: Landgraf A., Kübler S., Hintersberger E., Stein S. (Eds.). Seismicity, fault rupture and earthquake hazards in slowly deforming regions. London: Geological Society of London, Special Publication, 432, p. 73-90. https://doi.org/10.1144/SP432.5

Aitken M.J. 1998. An introduction to optical dating: the dating of Quaternary sediments by the use of photon-stimulated luminescence. Oxford: Oxford University Press, $267 \mathrm{p}$

Allmendinger R.W., González G. 2010. Neogene to Quaternary tectonics of the coastal Cordillera, northern Chile, Tectonophysics, 495(1-2):93-110. https://doi.org/10.1016/j.tecto.2009.04.019

Andrades Filho C.O., Guasselli L.A. 2008. Identificação de deformações neotectônicas, através de imagem SRTM, e sua relação com a gênese dos areais - sudoeste do Rio Grande do Sul. Revista Geográfica Acadêmica, 2(2):96-110.

Artur P.C., Soares P.C. 2002. Paleoestruturas e Petróleo na Bacia do Paraná, Brasil. Revista Brasileira de Geociências, 32(4):433-448

Asmus H.E., Ferrari A.L. 1978. Hipótese sobre a causa do tectonismo cenozóico na região Sudeste do Brasil. Série Projeto REMAC, 4, p. 75-88.

Assumpção M. 1998. Seismicity and stresses in the Brazilian passive margin. Bulletin of the Seismological Society of America, 88(1):160-169.

Assumpção M. 1992. The regional stress field in South America. Journal of Geophysical Research, 97(B8):11889-11903. https://doi. org/10.1029/91JB01590

Assumpção M., Barros L.V., Ferreira J., Dourado J.C. 2014. Intraplate seismicity in Brazil. In: Talwani P. (ed.). Intraplate seismicity. Cambridge: Cambridge University Press, p. 50-71.

Bigarella J., Mousinho M., Silva J. 1965. Pediplanos, pedimentos e seus depósitos correlativos no Brasil. Boletim Paranaense de Geografia, 16(17):117-151.

Bjornberg A.J.S., Gandolfi N., Paraguassu A.B. 1971. Basculamentos tectônicos modernos no Estado de São Paulo. In: Congresso Brasileiro de Geologia, 25., 1971, São Paulo, SP. Anais... 2, p. 159-174.

Borges M.S., Costa J.B.S., Hasui Y., Neto A.G.P., Morales N. 1998. Compartimentação neotectônica do sudeste do Brasil. In: Congresso Brasileiro de Geologia, 40., 1998, Belo Horizonte, MG. Anais... 74 p

Bull W.B. 2007. Tectonically active landscape. Oxford: Wiley-Blackwell, 333 p.

Burbank D.W., Anderson R.S. (eds). 2012. Tectonic Geomorphology. 2a ed. West Sussex: Wiley-Blackwell Science, $460 \mathrm{p}$.

Campanha G.A.C., Riccomini C., Melo M.S., Hasui Y., Almeida F.F.M., Dehira L.K. 1985. Análise do padrão de faturamento Mesozóico-Cenozóico das bacias tafrogênicas do sudeste do Brasil. In: Simpósio Regional de Geologia, 5., São Paulo. Atas... São Paulo: SBG, p. 337-350.

Chavez-Kus L.G., Salamuni E. 2008. Evidências da tensão N-S intraplaca no Neógeno. Complexo Atuba - região de Curitiba (PR). Revista Brasileira de Geociências, 38(3):439-454

Coblentz D.D., Richardson R.M. 1996. Analysis of the South American intraplate stress field. Journal of Geophysical Research, 101(4):8643-8657.

Cogné N., Gallagher K., Cobbold P.R. 2011. Post-rift reactivation of the onshore margin of southeast Brazil: Evidence from apatite (U-Th)/He and fission-track data. Earth and Planetary Science Letters, 309(1-2):118-130. https://doi.org/10.1016/j.epsl.2011.06.025

Costa R.D., Saadi A. 2005. Evolução do conhecimento sobre os campos de tensões neotectônicos do Brasil. In: Souza C.R.G., Suguio K., Oliveira A.M.S., Oliveira P.E de (Ed.). Quaternário do Brasil. Ribeirão Preto: Holos, p. 151-154.

Delvaux D., Sperner B. 2003. New aspects of tectonic stress inversion with reference to the TENSOR program. London: Geological Society of London, Special Publication, p. $75-100$

Doblas M. 1998. Slickenside kinematic indicators. Tectonophysics, 295(12):187-197. https://doi.org/10.1016/S0040-1951(98)00120-6

Etchebehere M.L.C., Saad A.R., Santoni G.C., Casado F.C., Fulfaro V.J. 2006. Detecção de prováveis deformações neotectônicas no vale do Rio do
Peixe, região ocidental paulista mediante aplicação de índices RDE (Relação Declividade-Extensão) em segmentos de drenagem. Revista Geociências Unesp, 25(3):271-289.

Fernandes L.A., Coimbra A.M. 1996. A Bacia Bauru (Cretáceo Superior, Brasil). Anais da Academia Brasileira de Ciências, 68(2):195-205.

Ferreira F.J.F. 1982. Integração de dados aeromagnéticos e geológicos: configuração e evolução tectônica do arco de Ponta-Grossa. MS Dissertation, Instituto de Geociências, Universidade de São Paulo, São Paulo, 170 p.

Flores J.A.A., Lisboa N.A., Baptista P.R.D. 1991. Caracterização morfotectônica e morfoestrutural do sudeste de Santa Catarina. In: Simpósio Nacional de Estudos Tectônicos, 3., 1991, Rio Claro. Anais... p. 101-102.

Foix N., Paredes J.M., Giacosa R.E. 2012. Upper Cretaceous-Paleocene extensional phase in the Golfo San Jorge basin (Argentina): Growth-fault model, paleoseismicity and paleostress analysis. Journal of South American Earth Sciences, 33(1):110-118. https://doi.org/10.1016/j.jsames.2011.07.005

Fortes E., Stevaux J.C., Volkmer S. 2005. Neotectonics and channel evolution of the Lower Ivinhema River: A right-bank tributary of the upper Paraná River, Brazil. Geomorphology, 70(3-4):325-338. https://doi.org/10.1016/j. geomorph.2005.02.011

Franco A.L., Etchebehere M.L.C., Stevaux J.C. 2008. Hipótese sobre os condicionantes neotectônicos do barramento natural da foz do Rio Ivaí (PR/ MS) com base em levantamento ecobatimétrico. Revista UnG, 7(1):78-86.

Franco A.O.B., Hackspacher P.C., Saad A.R., Guedes S., Hadler Neto J.C., Etchebehere M.L., Freitas R.F. 2005. Eventos de soerguimento mesocenozóicos no embasamento da região central do Arco de Ponta Grossa através da datação por traços de fissão em apatitas. In: Simpósio Nacional de Estudos Tectônicos, 10., 2005, Curitiba. Anais... p. 195-197.

Franco-Magalhães A.O.B., Hackspacher P.C., Glasmacher U.A., Saad A.R. 2010a. Rift to post-rift evolution of a "passive" continental margin: the Ponta Grossa Arch, SE Brazil. International Journal of Earth Science, 99(7):15991613. http://dx.doi.org/10.1007/s00531-010-0556-8

Franco-Magalhães A.O.B., Hackspacher P.C., Saad A.R. 2010b. Exumação tectônica e reativação de paleolineamentos no Arco de Ponta Grossa: termocronologia por traços de fissão em apatitas. Revista Brasileira de Geociências, 40(2):184-195

Frasca A.A.S., Lisboa N.A. 1993. Contribuição do sensoriamento remoto na compartimentação morfotectônica e morfoestrutural da Bacia do Paraná "Grupo São Bento", RS, e suas relações com as estruturas regionais do embasamento. In: Simpósio Brasileiro de Sensoriamento Remoto, 7., 1993, Curitiba. Anais... Curitiba. v. 3, p. 211-220.

Freitas R.O. 1950. Relevos policíclicos na tectônica do escudo brasileiro. Boletim Paulista de Geografia, (7):3-19.

Gallagher K., Hawkesworth C.J., Mantovani M.S.M. 1995. Denudation, fission track analysis and the long-term evolution of passive margin topography: application to the southeast Brazilian margin. Journal of South American Earth Sciences, 8(1):65-77. https://doi. org/10.1016/0895-9811(94)00042-Z

Garrote J., Heydt G.G., Cox R.T. 2008. Multi-stream order analyses in basin asymmetry: a tool to discriminate the influence of neotectonics in fluvial landscape development (Madrid Basin, Central Spain). Geomorphology, 102(1):130-144. https://doi.org/10.1016/j.geomorph.2007.07.023

Giambiagi L., Alvarez P., Spagnotto S. 2016. Temporal variation of the stress field during the construction of the central Andes: Constraints from the volcanic arc region $\left(22-26^{\circ} \mathrm{S}\right)$, Western Cordillera, Chile, during the last 20 Ma. Tectonics, 35(9):2014-2033. https://doi.org/10.1002/2016TC004201

Grohmann C.H., Riccomini C., Alves F.M. 2007. SRTM-based morphotectonic analysis of the Poço de Caldas Alkaline Massif, Southeastern Brazil. Computers \& Geosciences, 33(1):10-19. https://doi. org/10.1016/j.cageo.2006.05.002

Hadler J., Paulo S., Iunes P., Tello S.C., Balestrieri M., Bigazzi G., Curvo E.A.G., Hackspacher P. 2001. A PC compatible Brazilian software for obtaining thermal histories using apatite fission track analysis. Radiation Measurements, 34(1-6):149-154. http://dx.doi.org/10.1016/ S1350-4487(01)00141-X 
Harbor D., Bacastow A., Heath A., Rogers J. 2005. Capturing variable knickpoint retreat in the Central Appalachians, USA. Geografia Física e Dinâmica Quaternária, 28:23-36.

Hare P.H., Gardner T.W.M. 1985. Geomorphic Indicators of Vertical Neotectonism along Converging Plate Margins, Nicoya Peninsula, Costa Rica. In: Morisawa M., Hach J.T. (Eds.). Tectonic Geomorphology. Boston: Allen and Unwin, p. 75-104.

Harkins N., Kirby E., Heimsath A., Robinson R., Reiser U. 2007. Transient fluvial incision in the headwaters of the Yellow River, northeastern Tibet, China, Jour. Geophysical Research, 112(F3). http://dx.doi. org/10.1029/2006JF000570

Hasui Y. 1990. Neotectônica e aspectos da tectônica ressurgente no Brasil. In: Workshop sobre Neotectônica e Sedimentação Cenozóica no Sudeste do Brasil, 1., 1990, Belo Horizonte, MG. Anais... p. 1-31.

Hasui Y., Costa J.B.S., Borges M.S., Morales N., Jimenez-Rueda J.R. 1998. Evolução Morfotectônica do sudeste do Brasil. In: Congresso Brasileiro de Geologia, 40., 1998, Belo Horizonte, MG. Anais... 78 p.

Hiruma S.T., Riccomini C., Mondenesi-Gauttieri M.C., Hackspacher P.C., Hadler Neto J.C., Franco-Magalhães A.O.B. 2010. Denudation history of the Bocaina Plateau, Serra do Mar, southeastern Brazil: relationships to Gondwana breakup and passive margin development. Gondwana Research, 18(4):674-687. https://doi.org/10.1016/j.gr.2010.03.001

Holbrook J., Schumm S.A. 1999. Geomorphic and sedimentary response of rivers to tectonic deformation: a brief review and critique of a tool for recognizing subtle epeirogenic deformation in modern and ancient settings. Tectonophysics, 305:287-306

Jacques P.D., Machado R., Nummer A.R. 2015. Análise Estrutural da Formação Serra Geral na porção Centro-Sul do Estado de Santa Catarina, Brasil. Geociências, 34(3):390-401.

Jacques P.D., Salvador E.S., Machado R., Grohmann C.H., Nummer A.R 2014. Application of morphometry in neotectonic studies at the eastern edge of the Paraná Basin, Santa Catarina State, Brazil. Geomorphology, 213:13-23. https://doi.org/10.1016/j.geomorph.2013.12.037

Janasi V., Freitas V.A., Heaman L. 2011. The onset of flood basalt volcanism, Northern Paraná Basin, Brazil: a precise UPb baddeleyite/zircon age for a Chapecó-type dacite. Earth and Planetary Science Letters, 302(1-2):147153. https://doi.org/10.1016/j.epsl.2010.12.005

Karl M., Glasmacher U.A., Kollenz S., Franco-Magalhães A.O.B., Stockli D.F., Hackspacher P. 2013. Evolution of the South Atlantic passive continental margin in southern Brazil derived from zircon and apatite (UTh-Sm)/He and fission-track data. Tectonophysics, 604:224-244. https:// orcid.org/0000-0003-2125-3050

Keller E.A., Pinter N. 2002. Active tectonics: Earthquakes, uplift and landscape. Upper Saddle River, NJ: Prentice Hall, 362 p

Keller E.A., Rockwell T.K. 1984. Tectonic geomorphology, Quaternary chronology and paleoseismicity. In: Costa J.E. (Ed.) Developments and Applications of Geomorphology. New York: Springer-Verlag, p. 203-239.

King L.C. 1956. A geomorfologia do Brasil Oriental. Revista Brasileira de Geografia, 18(2):147-266.

Kirby E., Johnson C., Furlong K., Heimsath A. 2007. Transient channel incision along Bolinas Ridge, California: Evidence for differential rock uplift adjacent to the San Andreas fault. Journal of Geophysical Research, 112(F3). https://doi.org/10.1029/2006JF000559

Kröhling D., Brunetto E., Galina G., Zalazar M.C. 2011. Paleosurface analysis on the Cretaceous basaltic plateau on the Upper Rio Uruguay Basin (NE Argentina and Southern Brazil). Geociências, 30(1):31-46.

Lavenu A. 2006. Neotectónica de los Andes entre $1^{\circ} \mathrm{n}$ y $47^{\circ} \mathrm{s}$ (Ecuador, Bolivia y Chile): una revisión. Revista de la Asociación Geológica Argentina, 61(4):504-524.

Lavenu A., Cembrano J. 2008. Deformación compresiva cuaternaria en la Cordillera Principal de Chile central (Cajón del Maipo, este de Santiago) Revista Geológica de Chile, 35(2):233-252. http://dx.doi.org/10.4067/ S0716-02082008000200003

Lima C. 1998. Expressões topográficas e estruturais da compressão atuante na Placa Sul-Americana. In: Congresso Brasileiro de Geologia, 40., 1998, Belo Horizonte, MG. Anais... 79 p.
Lima O.N.B., Valadão R.C. 2002. Evolução do relevo adjacente à margem continental oriental brasileira: indicadores geológicos. In: Congresso Brasileiro de Geologia, 41., 2002, João Pessoa. Anais... João Pessoa: SBG. v. 1.

Machado R., Roldan L.F., Jacques P.D., Fassbinder E., Nummer A.R. 2012 Tectônica transcorrente Mesozoica-Cenozoica no Domo de Lages - Santa Catarina. Revista Brasileira de Geociências, 42(4):799-811. http://dx.doi. org $/ 10.5327 /$ Z0375-75362012000400011

Marotta G.S., França G.S., Monico G., Fuck R.A., Araújo Filho J.O. 2013. Strain rate of the South American lithospheric plate by SIRGAS-CON geodetic observations. Journal of South American Earth Sciences, 47 (5):136141. http://dx.doi.org/10.1016/j.jsames.2013.07.004

Milani E.J., Melo J.H.G., Souza P.A., Fernandes L.A., França A.B. 2007. Bacia do Paraná. Boletim de Geociências da Petrobras, 15(2):265-287.

Modica J.C., Brush E. 2004. Postrift sequence stratigraphy, paleogeography and fill history of the deep-water Santos Basin, offshore southeast Brazil. AAPG Bulletin, 88(7):923-945. https://doi.org/10.1306/01220403043

Morales N., Hasui Y., Souza I.A.S., Antonialli R.C. 2016. Reconstrução de eixos de paleotensão a partir de populações de falhas na região sudeste do Brasil. In: 48. Congresso Brasileiro de Geologia, 48., 2016, Porto Alegre, RS. Anais..

Morales N., Hasui Y., Souza I.A.S., Junior A.V.S., Machado F.B., Salamuni E. 2012. Padrão de fraturamento nas serras gaúchas: indícios de deformação pós-mesozóica a Recente em corredores de fraturas. In: Congresso Brasileiro de Geologia, 46., 2012, Santos, SP. Anais... CD-ROM.

Nardy A.J.R., Machado F.B., Oliveira M.A.F. 2008. As rochas vulcânicas mesozoicas ácidas da Bacia do Paraná: litoestratigrafia e considerações geoquímico-estratigráficas. Revista Brasileira de Geociências, 38(1):178-195.

Nascimento E.R., Salamuni E., Queiroz G.L., Hauck da Silva P.A., Fiori A.P. 2013. Evidências de determinação morfotectônica e neotectônica no relevo da Serra do Mar no estado do Paraná. Revista Brasileira de Geomorfologia, 14(3):287-299. http://dx.doi.org/10.20502/rbg.v14i3.402

National Aeronautics and Space Administration (NASA). Jet Propulsion Laboratory. Shuttle Radar Topography Mission. The mission to map the world Available at: http://www2.jpl.nasa.gov/srtm/. Accessed on: June 22, 2017.

Noblet C., Lavenu A., Marocco R. 1996. Concept of continuum as opposed to periodic tectonism in the Andes. Tectonophysics, 255 (1-2):65-78. https:// doi.org/10.1016/0040-1951(95)00081-X

Nummer A.R., Machado R., Jacques P.D. 2014. Tectônica transcorrente mesozoica/cenozoica na porção leste do Planalto do Rio Grande do Sul, Brasil. Pesquisas em Geociências, 41(2):121-130. https://doi. org/10.22456/1807-9806.78078

Oliveira C.H.E., Jelinek A.R. 2017. História termotectônica da margem continental brasileira a partir de dados de traços de fissão em apatita. Pesquisas em Geociências, 44(3):387-400. https://doi.org/10.22456/1807-9806.83263

Oliveira C.H.E., Jelinek A.R., Chemale Jr. F., Bernet M. 2016. Evidence of post-Gondwana breakup in Southern Brazilian Shield: Insights from apatite and zircon fission track thermochronology. Tectonophysics, 666:173-187. https://doi.org/10.1016/j.tecto.2015.11.005

Ouchi S. 1985. Response of alluvial rivers to slow active tectonic motion. Geological Society of America Bulletin, 96(4):504-515. https://doi. org/10.1130/0016-7606(1985)96\%3C504:ROARTS\%3E2.0.CO;2

Peate D.W., Hawkesworth C., Mantovani M.S.M. 1992. Chemical stratigraphy of the Paraná lavas (South America): classification of magma types and their spatial distribution. Bulletin of Volcanology, 55:119-139. https://doi.org/10.1007/BF00301125

Pérez-Peña J.V., Al-Awabdeh M., Azañón J.M., Galve J.P., Booth-Rea G., Notti D. 2017. SwathProfiler and NProfiler: Two new ArcGIS Add-ins for the automatic extraction of swath and normalized river profiles. Computers \& Geosciences, 104:135-150. https://doi.org/10.1016/j.cageo.2016.08.008

Petit J.P. 1987. Criteria for the sense of movement on fault surfaces in brittle rocks. Journal of Structural Geology, 9(5-6):597-608. https://doi. org/10.1016/0191-8141(87)90145-3

Peyerl W.L.P., Salamuni E., Sanches E., Nascimento E.R., Santos J.M., Gimenez V.B., Silva C.L., Farias T.F.S. 2018. Reactivation of Taxaquara Fault and its morphotectonic influence on the evolution of Jordão River catchment, Paraná. Brazilian Journal of Geology, 48(3):553-573. https:// doi.org/10.1590/2317-4889201820170110 
Queiroz G.L., Salamuni E., Nascimento E.R. 2014. AzimuthFinder: ferramenta para a extração de dados e apoio na análise estrutural. Geologia USP. Série Científica, 14(1):69-80. http://dx.doi.org/10.5327/ Z1519-874X201400010005

Reis J.P.P., Tomazzoli E.R. 2011. Morfotectônica da Serra do Tabuleiro, SC. In: Simpósio Nacional de Estudos Tectônicos, 13., 2011, Campinas. Anais... p. 352-355.

Riccomini C. 1995. Padrão de fraturamentos do Maciço Alcalino de Cananéia, estado de São Paulo: relações com a tectônica mesozóico-cenozóica do Sudeste do Brasil. Revista Brasileira de Geociências, 25(2):79-84.

Riccomini C., Peloggia A., Saloni J., Kohnke M., Figueira R. 1989. Neotectonic activity in the Serra do Mar rift system (southeastern Brazil). Journal of South American Earth Sciences, 2(2):191-197. https://doi. org/10.1016/0895-9811(89)90046-1

Roldan L.F., Machado R., Steiner S.S., Warren L.V. 2010. Análise de lineamentos estruturais no Domo de Lages (SC) com uso de imagens de satélite e mapas de relevo sombreado. Geologia USP. Série Científica, 10(2):57-72. https://doi.org/10.5327/Z1519-874X2010000200005

Saadi A. 1993. Neotectônica da plataforma brasileira: esboço e interpretação preliminares. Geonomos, 1(1-2):1-15. https://doi.org/10.18285/ geonomos.v1ile2.233

Saadi A., Machette M.N., Haller K.M., Dart R.L., Bradley L., Souza A.M.P.D. 2002. Map and Database of Quaternary Faults and Lineaments in Brazil. International Lithosphere Program Task Group II-2, Major Active Faults of the World. Denver, Colorado.

Salamuni E., Ebert H.D., Hasui Y. 2004. Morfotectônica da bacia sedimentar de Curitiba. Revista Brasileira de Geociências, 34(4):469.

Salvador E.D., Riccomini C. 1995. Neotectônica da região do Alto Estrutural de Queluz (SP-RJ, Brasil). Revista Brasileira de Geociências, 25(3):151-164.

Santos J.M., Salamuni E., Silva C.L., Sanches E., Barbosa-Gimenez V., Nascimento E.R. 2019. Morphotectonics in the central-east region of South Brazil: implications for catchments of the Lava-Tudo and Pelotas rivers, State of Santa Catarina. Geomorphology, 328:138-156. https://doi. org/10.1016/j.geomorph.2018.12.016

Santos L.F.F., Guedes I.V., Etchebehere M.L.C. 2011. Análise neotectônica do Pontal do Paranapanema (SP) mediante aplicação de parâmetros fluviométricos. Geociências, 30(4):491-507.

Scheibe L.F., Kawashita K., Gomes C.B. 1985. Contribuição à geocronologia do Complexo Alcalino de Lages, SC. In: Simpósio Sul-Brasileiro de Geologia, 2, Anais... SBG. p. 299-307.

Schuck M.T.G.O., Lisboa N.A., Dani N., Haertel V. 2001. Correlação de dados morfotectônicos e geomorfogenéticos na pesquisa do manto de alteração de rocha do planalto Sul-Riograndense. Revista Brasileira de Geociências, 21(4):363-370.

Schumm S.A. 1956. The evolution of drainage systems and slopes in badlands at PerthÚmboi, New Jersey. Bulletin of the Geological Society of America, 67(5):597-646. https://doi.org/10.1130/0016-7606(1956)67[597:EOD SAS $] 2.0 . \mathrm{CO} ; 2$

Schumm S.A. 1986. Alluvial river response to active tectonics. In: Studies in Geophysics (Ed.). Active Tectonics. Washington, D.C.: National Academy Press, p. 80-94.

Sébrier M., Lavenu A., Fornari M., Soulas J.-P. 1988. Tectonics and uplift in Central Andes (Peru, Bolivia, and Northern Chile) from Eocene to present. Géodynamics, 3(1-2):85-106.

Silva T.P., Mello C.L. 2011. Reativações Neotectônicas na Zona de Cisalhamento do Rio Paraíba do Sul (Sudeste do Brasil). Geologia USP. Série Científica, 11(1):95-111. https://doi.org/10.5327/Z1519-874X2011000100006

Siqueira-Ribeiro M.C., Hackspacher P.C., Ribeiro L.F.B., Hadler Neto J.C. 2011. Evolução Tectônica e Denudacional da Serra do Mar (SE/BRASIL) no limite entre o Cretáceo Superior e Paleoceno, utilizando análises de traços de fissão e U-TH/HE em apatitas. Revista Brasileira de Geomorfologia, 12(Esp. N.):3-14. http://dx.doi.org/10.20502/rbg.v12i0.254

Snyder N.P., Whipple K.X., Tucker G.E., Merritts D.J. 2000. Landscape response to tectonic forcing: Digital elevation model analysis of stream profiles in the Mendocino triple junction region, northern California. Geological Society of America Bulletin, 112(8):1250-1263. https://doi. org/10.1130/0016-7606(2000)112\%3C1250:LRTTFD\%3E2.0.CO;2
Soares A.P., Soares P.C., Bettú D.F., Holz M. 2007. Compartimentação estrutural da Bacia do Paraná: a questão dos lineamentos e sua influência na distribuição do Sistema Aquífero Guarani. Geociências, 26(4):297-311.

Soares P.C., Riffel S.B., Fiori A.P. 2011. Geomorphological and geophysical evidences for neotectonics, central and southern Brazil. In: Simpósio Nacional de Estudos Tectônicos, 7., 2011, Campinas. Anais... p. 401-404.

Sordi M.V., Salgado A.A.R., Siame L., Bourlès D., Paisani J.C., Léanni L., Braucher R., Couto E.V., Aumaître G., Keddadouche K. 2018. Implications of drainage rearrangement for passive margin escarpment evolution in southern Brazil. Geomorphology, 306:155-169. https://doi.org/10.1016/j. geomorph.2018.01.007

Souza Filho E.E. 1995. Efeitos de movimentos tectônicos cenozóicos sobre o Rio Paraná na região de Porto Rico (PR) e Nova Andradina (MS). In: Simpósio de Geologia do Sudeste, 1995, Águas de São Pedro. Anais... 91 p.

Souza Junior M.D., Santos M.L., Salamuni E., Stevaux J.C., Morales N. 2013. Análise morfotectônica da bacia hidrográfica do rio Ivaí-PR, curso inferior. Revista Brasileira de Geomorfologia, 14(2):211-218. http://dx.doi. org/10.20502/rbg.v14i2.380

Strahler A. 1945. Hypotheses of stream development in the folded Appalachians of Pennsylvania. GeologicalSociety ofAmericaBulletin, 56(1):4588. https://doi.org/10.1130/0016-7606(1945)56[45:HOSDIT]2.0.CO;2

Thiede D.S., Vasconcelos P.M. 2010. Paraná flood basalts: rapid extrusion hypothesis confirmed by new 40Ar/39Ar results. Geology, 38(8):747-750. https://doi.org/10.1130/G30919.1

Tomazzoli E.R. 2002. Evidências de neotectônica na ilha de Santa Catarina e área continental adjacente. In: Congresso Brasileiro de Geologia, 41., 2002, João Pessoa, PB. Anais... 371 p.

Tomazzoli E.R., Pellerin J.R.M. 2001. Evidências de neotectônica no vale do rio Cubatão, Santa Catarina. In: Congresso da Associação Brasileira de Estudos do Quaternário, 8., 2001. Anais... v. 1, p. 307-308.

Twidale C.R. 1985. Old landsurfaces and their implications for models of landscape evolution. Revue Geomorphologie Dynamique, 34:131-147.

Val P.F.A., Silva C.L., Santos J.M., Morales N.; Harbor D. 2013. Distribuição de knickpoints em bacias de drenagem na região de Manaus (AM) e seu potencial para o estudo neotectônico e evolução da paisagem. In: Wankler F.L., Holanda E.C., Vasquez M.L. (Eds.). Contribuições à Geologia da Amazônia, v. 8, p. 7-24. Sociedade Brasileira de Geologia.

Valadão R.C.2009. Geodinâmica de superfícies de aplanamento, desnudação continental e tectônica ativa como condicionantes da megageomorfologia do Brasil oriental. Revista Brasileira de Geomorfologia, 10(2):77-90. http:// dx.doi.org/10.20502/rbg.v10i2.132

Whipple K.X., Meade B.J. 2004. Controls on the strength of coupling among climate, erosion, and deformation in two sided, frictional orogenic wedges at steady state. Journal of Geophysical Research, 109(F1). http:// dx.doi.org/10.1029/2003JF000019

Wildner W., Camozzato E., Toniolo J.A., Binotto R.B., Iglesias C.M.F., Laux J.H. 2004. Mapa geológico do estado de Santa Catarina. Escala 1:500.000. CPRM-Programa Geologia do Brasil. Subprograma de Cartografia Geológica Regional. Porto Alegre.

Wildner W., Licht W., Arioli O.A.B. 2006. Geologia e Recursos Minerais do Sudoeste do Estado do Paraná. Escala 1:200.000. Brasília: CPRM. (Convênio CPRM/MINEROPAR).

Wobus C., Whipple K.X., Kirby E., Snyder N., Johnson J., Spyropolou K., Crosby B., Sheehan D. 2006. Tectonics from topography: procedures, promise, and pitfalls. In: Willett S.D., Hovius N., Brandon M.T., Fisher D.M. (Eds.). Tectonics, Climate and Landscape Evolution, Special Paper, v. 304, p. 55-74. Boulder, Geological Society of America.

Zalán P.V., Oliveira J.A.B. 2006. Origem e evolução estrutural do sistema de riftes Cenozóicos do sudeste do Brasil. In: Simpósio do Cretáceo do Brasil, 7., e Simpósio do Terciário do Brasil, 1., 2006. Anais...

Zalán P.V., Wolf S., Conceição J.C.J., Astolfi M.A.M., Vieira I.S., Appi V.T., Zanotto O.A. 1987. Tectônica e sedimentação da Bacia do Paraná. In: Simpósio Sul-Brasileiro de Geologia, 3., 1987, Curitiba. Anais... v. 1, p. 441473. Curitiba: SBG.

Zalán P.V., Wolff S., Conceição J.C.J., Marques A., Astolfi M.A.M., Vieira I.S., Appi V.T., Zanotto O.A. 1990. Bacia do Paraná. In: Raja Gabaglia G.P., Milani E.J. (eds.). Origem e Evolução de Bacias Sedimentares, p. 681-708. Petrobras. 